\title{
Índice do volume RBEP
}

Este índice refere-se às matérias do volume 101 (números 257, 258 e 259) da Revista Brasileira de Estudos Pedagógicos. Divide-se em três partes, de acordo com os diferentes pontos de acesso: Assuntos, Autores e Títulos.

Quanto ao Índice de Assuntos:

- os termos usados para indexação são extraídos do Thesaurus Brasileiro de Educação (Brased);

- cada palavra dos termos compostos abre uma entrada, por exemplo:

Avaliação do ensino superior ensino superior, Avaliação do

superior, Avaliação do ensino

Quanto ao Índice de Autores:

- arrolados pelo último sobrenome;

- um traço é usado para substituir o nome quando há mais de uma entrada para o mesmo autor.

Quanto ao Índice de Títulos:

- os artigos que iniciam o título não são considerados. 



\section{íNDICC DE ASSUNros BBEEP}

Alteridade - interculturalidade - migração boliviana.

GONDIN, Janaina Silva; PINEZI, Ana Keila Mosca; MENEZES, Marilda de Aparecida. Alteridade e interculturalidade na escola: um estudo etnográfico sobre estudantes bolivianos em São Paulo. RBEP, Brasília, v. 101, n. 259, p. 607-626, set./dez. 2020. Seção: Estudos.

Ambiente educativo - educação inclusiva - formação continuada do professor.

VIEIRA, Alexandro Braga; JESUS, Denise Meyrelles de; LIMA, Jovenildo da Cruz; MARIANO, Clayde Aparecida Belo da Silva. As contribuições de Meirieu para a formação continuada de professores e a adoção de práticas pedagógicas inclusivas. RBEP, Brasília, v. 101, n. 258, p. 503-522, maio/ago. 2020. Seção: Relatos de Experiência.

Ambiente virtual de aprendizagem - metodologia do ensino - teorias de aprendizagem.

AGONÁCS, Nikoletta; MATOS, João Filipe. Os Cursos On-line Abertos e Massivos (Mooc) como ambientes heutagógicos. RBEP, Brasília, v. 101, n. 257, p. 17-35, jan./abr. 2020. Seção: Estudos.

América Latina - educación superior - investigación - universidad. CAREGNATO, Célia Elizabete; SANTIN, Dirce Maria; DEL VALLE, Dámian; TAKAYANAGUI, Axel Didriksson. Educación superior y universidad en América Latina: perspectivas temáticas para debates e investigaciones. RBEP, Brasília, v. 101, n. 259, p. 670-690, set./dez. 2020. Seção: Estudos. 
Análise da informação - identidade racial - sistema de cotas.

FREITAS, Matheus; SARMENTO, Rayza. As falas sobre a fraude: análise das notícias sobre casos e fraudes nas cotas raciais em universidades em Minas Gerais. RBEP, Brasília, v. 101, n. 258, p. 271-294, maio/ago. 2020. Seção: Estudos.

Análise de correspondência - análise fatorial - autoeficácia professores - satisfação no trabalho.

FERREIRA, Enizete Andrade; RAMOS, Maely Ferreira Holanda; RAMOS, Edson Marcos Leal Soares; COUTO, Andréa Lobato. Autoeficácia, satisfação no trabalho, aspectos sociodemográficos e condições de trabalho de docentes-alunos do PARFOR. RBEP, Brasília, v. 101, n. 258, p. 337-358, maio/ago. 2020. Seção: Estudos.

Análise fatorial - análise de correspondência - autoeficácia professores - satisfação no trabalho.

FERREIRA, Enizete Andrade; RAMOS, Maely Ferreira Holanda; RAMOS, Edson Marcos Leal Soares; COUTO, Andréa Lobato. Autoeficácia, satisfação no trabalho, aspectos sociodemográficos e condições de trabalho de docentes-alunos do PARFOR. RBEP, Brasília, v. 101, n. 258, p. 337-358, maio/ago. 2020. Seção: Estudos.

Análise linguística - prática pedagógica - formação de professores. SUASSUNA, Lívia. O ensino de análise linguística por estagiários da licenciatura em Letras. RBEP, Brasília, v. 101, n. 257, p. 57-78, jan./abr. 2020. Seção: Estudos.

Artigo científico - concepção de escrita - produção científica.

SILVA, Elizabeth Maria da; SILVA, Maria Ariane Santos Amaro da; CUNHA, Raquel Laurentino; BRITO, Júlia Juliêta Silva de. O que é um "bom" artigo científico? Concepções de estudantes do curso de Engenharia Elétrica. RBEP, Brasília, v. 101, n. 259, p. 771-786, set./dez. 2020. Seção: Estudos.

Atualização de professores - educação básica - identidade profissional. ROSSI, Fernanda; HUNGER, Dagmar. Identidade docente e formação continuada: um estudo à luz das teorias de Zygmunt Bauman e Claude Dubar. RBEP, Brasília, v. 101, n. 258, p. 313-336, maio/ago. 2020. Seção: Estudos.

Autoeficácia - análise de correspondência - análise fatorial professores - satisfação no trabalho.

FERREIRA, Enizete Andrade; RAMOS, Maely Ferreira Holanda; RAMOS, Edson Marcos Leal Soares; COUTO, Andréa Lobato. Autoeficácia, satisfação no trabalho, aspectos sociodemográficos e condições de trabalho de docentes-alunos do PARFOR. RBEP, Brasília, v. 101, n. 258, p. 337-358, maio/ago. 2020. Seção: Estudos.

Avaliação de desempenho discente - Educação Física - relatório de pesquisa.

BARROS, João Luiz da Costa; CAMPOS, Márcia Zendron de; TEIXEIRA, Denilson de Castro; CABRAL, Breno Guilherme de Araujo Tinoco. Reflexões 
sobre o nível de conhecimentos específicos dos estudantes de licenciatura em Educação Física no Enade 2014. RBEP, Brasília, v. 101, n. 257, p. 99-119, jan./abr. 2020. Seção: Estudos.

Avaliação do livro didático - ilustrações do livro didático neuroeducação.

SILVA, Kleyfton Soares da; FONSECA, Laerte Silva da. Bases neuroeducativas do papel das ilustrações: uma proposta de análise de livro didático. RBEP, Brasília, v. 101, n. 257, p. 36-56, jan./abr. 2020. Seção: Estudos.

Base Nacional Comum Curricular - Parâmetros Curriculares Nacionais programa de alfabetização.

GUILLEN, Cássia Helena; MIGUEL, Maria Elisabeth Blanck. A alfabetização nos Parâmetros Curriculares Nacionais (PCN) e na Base Nacional Comum Curricular (BNCC): o que mudou de 1997 a 2017. RBEP, Brasília, v. 101, n. 259, p.567-582, set./dez. 2020. Seção: Estudos.

Centro integrado de ensino - Enem - políticas públicas.

NASCIMENTO, Matheus Monteiro; CAVALCANTI, Cláudio; OSTERMANN, Fernanda. Dez anos de instituição da Rede Federal de Educação Profissional, Científica e Tecnológica: o papel social dos institutos federais. RBEP, Brasília, v. 101, n. 257, p. 120-145, jan./abr. 2020. Seção: Estudos.

Certificação de saberes docentes - educação profissional - formação dos profissionais da educação - Rede Certific.

FASSINA, Ana Paula; WOLLINGER, Paulo; ALLAIN, Olivier. Certificação de saberes docentes na educação profissional: construção de um projetopiloto. RBEP, Brasília, v. 101, n. 259, p. 787-809, set./dez. 2020. Seção: Relatos de Experiência.

Ciudadanía y educación - currículo mínimo nacional - desarrollo sostenible.

DIÓGENES, Camila Gomes; VALOYES VALOYES, Angie Yirlesa; EUZEBIO, Umberto. Implementación de la competencia 10 de la Base Nacional Cómun Curricular en Brasil: un análisis desde el concepto de Ciudadanía Global de la Agenda 2030. RBEP, Brasília, v. 101, n. 259, p. 583-606, set./dez. 2020. Seção: Estudos.

Colonialidade - interdisciplinaridade - práxis pedagógica.

RAMOS, Luiza Olivia Lacerda; FERREIRA, Rosilda Arruda. Sobre uma práxis interdisciplinar: aproximações e proposições conceituais. RBEP, Brasília, v. 101, n. 257, p. 197-216, jan./abr. 2020. Seção: Estudos.

Concepção de escrita - artigo científico - produção científica. CUNHA, Raquel Laurentino; SILVA, Elizabeth Maria da; SILVA, Maria Ariane Santos Amaro da; BRITO, Júlia Juliêta Silva de. O que é um "bom" artigo científico? Concepções de estudantes do curso de Engenharia Elétrica. RBEP, Brasília, v. 101, n. 259, p. 771-786, set./dez. 2020. Seção: Estudos. 
Cultura digital - emoções - estudos socioculturais - tecnologia educacional.

BROCHADO, Eliana Alice; HORNINK, Gabriel Gerber. Emoções experienciadas no processo de construção de narrativas digitais no Scratch. RBEP, Brasília, v. 101, n. 259, p. 627-648, set./dez. 2020. Seção: Estudos.

Currículo - educação infantil - prática pedagógica.

DOMINICO, Eliane; LIRA, Aliandra Cristina Mesomo; SAITO, Heloisa Toshie Irie; YAEGASHI, Solange Franci Raimundo. Práticas pedagógicas na educação infantil: o currículo como instrumento de governo dos pequenos. RBEP, Brasília, v. 101, n. 257, p. 217-236, jan./abr. 2020. Seção: Estudos.

Currículo mínimo nacional - ciudadanía y educación - desarrollo sostenible.

DIÓGENES, Camila Gomes; VALOYES VALOYES, Angie Yirlesa; EUZEBIO, Umberto. Implementación de la competencia 10 de la BNCC en Brasil: un análisis desde el concepto de Ciudadanía Global de la Agenda 2030. RBEP, Brasília, v. 101, n. 259, p. 583-606, set./dez. 2020. Seção: Estudos.

Curso de licenciatura - educação comparada - modelo de formação docente.

CACHAPUZ, António Francisco; SHIGUNOV NETO, Alexandre; SILVA, André Coelho da. Formação inicial de professores de Física no Brasil e em Portugal: uma análise comparativa de modelos de formação. RBEP, Brasília, v. 101, n. 257, p. 146-163, jan./abr. 2020. Seção: Estudos.

Curso e currículo - Pedagogia - políticas públicas em educação.

FERREIRA, Liliana Soares; MACHADO, Célia Tanajura; MARASCHIN, Mariglei Severo; DE TONI, Dulcineia Libraga Papalia. Políticas educacionais e os impactos sobre processos educativos nos cursos de pedagogia: uma análise. RBEP, Brasília, v. 101, n. 258, p. 295-312, maio/ago. 2020. Seção: Estudos.

Desarrollo sostenible - ciudadanía y educación - currículo mínimo nacional.

DIÓGENES, Camila Gomes; VALOYES VALOYES, Angie Yirlesa; EUZEBIO, Umberto. Implementación de la competencia 10 de la Base Nacional Cómun Curricular en Brasil: un análisis desde el concepto de Ciudadanía Global de la Agenda 2030. RBEP, Brasília, v. 101, n. 259, p. 583-606, set./dez. 2020. Seção: Estudos.

Desempenho em matemática - funções executivas - memória.

SANTANA, Alanny Nunes de; ROAZZI, Antonio; MELO, Monilly Ramos Araújo. Os três componentes executivos básicos e o desempenho matemático escolar. RBEP, Brasília, v. 101, n. 259, p. 649-669, set./dez. 2020. Seção: Estudos.

Docência - educação compensatória - representação social.

ROSSO, Ademir José; SILVA, Bruna Emilyn da; OLIVEIRA, Vânia Katzenwadel de; SANTOS, Franciely Ribeiro dos. Representações sociais 
de trabalhadores com baixa escolaridade sobre o trabalho docente. RBEP, Brasília, v. 101, n. 258, p. 359-381, maio/ago. 2020. Seção: Estudos.

Docência no ensino superior - licenciatura - metodologia. ROCATELI, Adrielly; FRANCO, Sandra Aparecida Pires; GALVÃO, Rosangela Miola; CASAGRANDE, Fernanda Couto Guimarães. Trabalho pedagógico nos cursos de licenciatura da Universidade Estadual de Londrina: metodologias em questão. RBEP, Brasília, v. 101， n. 259, p. 752-770, set./dez. 2020. Seção: Estudos.

Educação básica - atualização de professores - identidade profissional. ROSSI, Fernanda; HUNGER, Dagmar. Identidade docente e formação continuada: um estudo à luz das teorias de Zygmunt Bauman e Claude Dubar. RBEP, Brasília, v. 101, n. 258, p. 313-336, maio/ago. 2020. Seção: Estudos.

Educação comparada - curso de licenciatura - modelo de formação docente.

CACHAPUZ, António Francisco; SHIGUNOV NETO, Alexandre; SILVA, André Coelho da. Formação inicial de professores de Física no Brasil e em Portugal: uma análise comparativa de modelos de formação. RBEP, Brasília, v. 101, n. 257, p. 146-163, jan./abr. 2020. Seção: Estudos.

Educação compensatória - docência - representação social.

ROSSO, Ademir José; SILVA, Bruna Emilyn da; OLIVEIRA, Vânia Katzenwadel de; SANTOS, Franciely Ribeiro dos. Representações sociais de trabalhadores com baixa escolaridade sobre o trabalho docente. RBEP, Brasília, v. 101, n. 258, p. 359-381, maio/ago. 2020. Seção: Estudos.

Educação Física - avaliação de desempenho discente - relatório de pesquisa.

BARROS, João Luiz da Costa; CAMPOS, Márcia Zendron de; TEIXEIRA, Denilson de Castro; CABRAL, Breno Guilherme de Araujo Tinoco. Reflexões sobre o nível de conhecimentos específicos dos estudantes de licenciatura em Educação Física no Enade 2014. RBEP, Brasília, v. 101, n. 257, p. 99-119, jan./abr. 2020. Seção: Estudos.

Educação física - formação de professores - pós-graduação stricto sensu.

TEIXEIRA, Fabiane Castilho; SOUZA, Juliano de; BROCH, Caroline; BARBOSA-RINALDI, Ieda Parra. Entre pesquisa e docência: notas sobre o projeto formativo stricto sensu em Educação Física. RBEP, Brasília, v. 101, n. 257, p. 164-181, jan./abr. 2020. Seção: Estudos.

Educação inclusiva - ambiente educativo - formação continuada do professor.

VIEIRA, Alexandro Braga; JESUS, Denise Meyrelles de; LIMA, Jovenildo da Cruz; MARIANO, Clayde Aparecida Belo da Silva. As contribuições de Meirieu para a formação continuada de professores e a adoção de práticas 
pedagógicas inclusivas. RBEP, Brasília, v. 101, n. 258, p. 503-522, maio/ago. 2020. Seção: Relatos de Experiência.

Educação infantil - currículo - prática pedagógica.

DOMINICO, Eliane; LIRA, Aliandra Cristina Mesomo; SAITO, Heloisa Toshie Irie; YAEGASHI, Solange Franci Raimundo. Práticas pedagógicas na educação infantil: o currículo como instrumento de governo dos pequenos. RBEP, Brasília, v. 101, n. 257, p. 217-236, jan./abr. 2020. Seção: Estudos.

Educação Moral e Cívica - educação na ditadura civil-militar - Grupo Escolar Dom Benevides.

CARVALHO, Rosana Areal; SILVA, Fernanda Aparecida Oliveira Rodrigues; EVANGELISTA, Raquel Jesus. A disciplina Educação Moral e Cívica no Grupo Escolar Dom Benevides em Mariana/MG (1969-1975). RBEP, Brasília, v. 101, n. 258, p. 458-480, maio/ago. 2020. Seção: Estudos.

\section{Educação na ditadura civil-militar - Educação Moral e Cívica - Grupo Escolar Dom Benevides.}

CARVALHO, Rosana Areal; SILVA, Fernanda Aparecida Oliveira Rodrigues; EVANGELISTA, Raquel Jesus. A disciplina Educação Moral e Cívica no Grupo Escolar Dom Benevides em Mariana/MG (1969-1975). RBEP, Brasília, v. 101, n. 258, p. 458-480, maio/ago. 2020. Seção: Estudos.

Educação profissional - certificação de saberes docentes - formação dos profissionais da educação - Rede Certific.

FASSINA, Ana Paula; WOLLINGER, Paulo; ALLAIN, Olivier. Certificação de saberes docentes na educação profissional: construção de um projetopiloto. RBEP, Brasília, v. 101, n. 259, p. 787-809, set./dez. 2020. Seção: Relatos de Experiência.

Educação superior - evidência científica - saúde e educação. FERRAZ, Lucimare; SCHNEIDER, Luana Roberta; PEREIRA, Rui Pedro Gomes; PEREIRA, Altamiro Manuel Rodrigues Costa. Ensino e aprendizagem da prática baseada em evidências nos cursos de Enfermagem e Medicina. RBEP, Brasília, v. 101, n. 257, p. 237-250, jan./abr. 2020. Seção: Relatos de Experiência.

Educação superior - gestão - instituição comunitária de ensino mercantilização do ensino.

FIOREZE, Cristina. Gestão das IES privadas sem fins lucrativos diante dos tensionamentos da mercantilização da educação superior e o caso das universidades comunitárias regionais: a caminho do hibridismo. RBEP, Brasília, v. 101, n. 257, p. 79-98, jan./abr. 2020. Seção: Estudos.

Educación superior - América Latina - investigación - universidad. CAREGNATO, Célia Elizabete; SANTIN, Dirce Maria; DEL VALLE, Dámian; TAKAYANAGUI, Axel Didriksson. Educación superior y universidad en América Latina: perspectivas temáticas para debates e investigaciones. RBEP, Brasília, v. 101, n. 259, p. 670-690, set./dez. 2020. Seção: Estudos. 
Emoções - cultura digital - estudos socioculturais - tecnologia educacional.

BROCHADO, Eliana Alice; HORNINK, Gabriel Gerber. Emoções experienciadas no processo de construção de narrativas digitais no Scratch. RBEP, Brasília, v. 101, n. 259, p. 627-648, set./dez. 2020. Seção: Estudos.

Enade-Química - nível cognitivo de dificuldade - processo cognitivo. SILVA, Márcia Gorette Lima da; MAZZÉ, Fernanda. O que avalia a prova do Enade de Química?: Uma proposta de análise em termos de operações cognitivas. RBEP, Brasília, v. 101, n. 259, p. 721-751, set./dez. 2020. Seção: Estudos.

Enem - centro integrado de ensino - políticas públicas.

NASCIMENTO, Matheus Monteiro; CAVALCANTI, Cláudio; OSTERMANN, Fernanda. Dez anos de instituição da Rede Federal de Educação Profissional, Científica e Tecnológica: o papel social dos institutos federais. RBEP, Brasília, v. 101, n. 257, p. 120-145, jan./abr. 2020. Seção: Estudos.

Ensino da tecnologia - espaços experimentais - experimentação construtiva.

LAVERDE, Albenise; OLIVEIRA, Cláudia Terezinha de Andrade. Os espaços experimentais das escolas públicas de arquitetura do Brasil: realidade ou utopia? RBEP, Brasília, v. 101, n. 258, p. 436-457, maio/ago. 2020. Seção: Estudos.

Ensino de arte - escola-parque - pesquisa da educação.

VASCONCELOS, Rafaella Lira Silva dos Santos de; WIGGERS, Ingrid Dittrich. A arte nas escolas-parque de Brasília: concepções do trabalho pedagógico. RBEP, Brasília, v. 101, n. 259, p. 547-566, set./dez. 2020. Seção: Estudos.

Ensino superior - história da educação - química.

SANTOS, Ademir Valdir dos; CUSTODIO, Renato da Silva. A serviço da Medicina: origem da disciplina de Química no Compêndio Histórico da Universidade de Coimbra (1771). RBEP, Brasília, v. 101, n. 257, p. 182-196, jan./abr. 2020. Seção: Estudos.

Escola-parque - ensino de arte - pesquisa da educação.

VASCONCELOS, Rafaella Lira Silva dos Santos de; WIGGERS, Ingrid Dittrich. A arte nas escolas-parque de Brasília: concepções do trabalho pedagógico. RBEP, Brasília, v. 101, n. 259, p. 547-566, set./dez. 2020. Seção: Estudos.

Espaços experimentais - ensino da tecnologia - experimentação construtiva.

LAVERDE, Albenise; OLIVEIRA, Cláudia Terezinha de Andrade. Os espaços experimentais das escolas públicas de arquitetura do Brasil: realidade ou utopia? RBEP, Brasília, v. 101, n. 258, p. 436-457, maio/ago. 2020. Seção: Estudos. 
Estratégia de aprendizagem - metodologia de ensino - motivação do estudante.

HONÓRIO, Daniel Augusto; JESUS, Josiane Aparecida de; FIN, Gracielle; NODARI JÚNIOR, Rudy José. Perfil motivacional, formas de estudo e satisfação com a vida de estudantes universitários. RBEP, Brasília, v. 101, n. 258, p. 420-435, maio/ago. 2020. Seção: Estudos.

Estudo de caso - política ambiental - prática de educação ambiental. FARIAS FILHO; Everaldo Nunes de; FARIAS, Carmen Roselaine de Oliveira. Duas décadas da Política Nacional de Educação Ambiental: percepções de professores no contexto de uma escola pública de Pernambuco. RBEP, Brasília, v. 101, n. 258, p. 481-502, maio/ago. 2020. Seção: Relatos de Experiência.

Estudos socioculturais - cultura digital - emoções - tecnologia educacional.

BROCHADO, Eliana Alice; HORNINK, Gabriel Gerber. Emoções experienciadas no processo de construção de narrativas digitais no Scratch. RBEP, Brasília, v. 101, n. 259, p. 627-648, set./dez. 2020. Seção: Estudos.

Evidência científica - educação superior - saúde e educação.

FERRAZ, Lucimare; SCHNEIDER, Luana Roberta; PEREIRA, Rui Pedro Gomes; PEREIRA, Altamiro Manuel Rodrigues Costa. Ensino e aprendizagem da prática baseada em evidências nos cursos de Enfermagem e Medicina. RBEP, Brasília, v. 101, n. 257, p. 237-250, jan./abr. 2020. Seção: Relatos de Experiência.

Experimentação construtiva - ensino da tecnologia - espaços experimentais.

LAVERDE, Albenise; OLIVEIRA, Cláudia Terezinha de Andrade. Os espaços experimentais das escolas públicas de arquitetura do Brasil: realidade ou utopia? RBEP, Brasília, v. 101, n. 258, p. 436-457, maio/ago. 2020. Seção: Estudos.

Formação continuada do professor - ambiente educativo - educação inclusiva.

VIEIRA, Alexandro Braga; JESUS, Denise Meyrelles de; LIMA, Jovenildo da Cruz; MARIANO, Clayde Aparecida Belo da Silva. As contribuições de Meirieu para a formação continuada de professores e a adoção de práticas pedagógicas inclusivas. RBEP, Brasília, v. 101, n. 258, p. 503-522, maio/ago. 2020. Seção: Relatos de Experiência.

Formação de professores - educação física - pós-graduação stricto sensu.

TEIXEIRA, Fabiane Castilho; SOUZA, Juliano de; BROCH, Caroline; BARBOSA-RINALDI, Ieda Parra. Entre pesquisa e docência: notas sobre o projeto formativo stricto sensu em Educação Física. RBEP, Brasília, v. 101,

n. 257, p. 164-181, jan./abr. 2020. Seção: Estudos. 
Formação de professores - prática pedagógica - análise linguística. SUASSUNA, Lívia. O ensino de análise linguística por estagiários da licenciatura em Letras. RBEP, Brasília, v. 101, n. 257, p. 57-78, jan./abr. 2020. Seção: Estudos.

Formação dos profissionais da educação - certificação de saberes docentes - educação profissional - Rede Certific.

FASSINA, Ana Paula; WOLLINGER, Paulo; ALLAIN, Olivier. Certificação de saberes docentes na educação profissional: construção de um projeto piloto. RBEP, Brasília, v. 101, n. 259, p. 787-809, set./dez. 2020. Seção: Relatos de Experiência.

Funções executivas - desempenho em matemática - memória. SANTANA, Alanny Nunes de; ROAZZI, Antonio; MELO, Monilly Ramos Araújo. Os três componentes executivos básicos e o desempenho matemático escolar. RBEP, Brasília, v. 101, n. 259, p. 649-669, set./dez. 2020. Seção: Estudos.

Gestão - educação superior - instituição comunitária de ensino mercantilização do ensino.

FIOREZE, Cristina. Gestão das IES privadas sem fins lucrativos diante dos tensionamentos da mercantilização da educação superior e o caso das universidades comunitárias regionais: a caminho do hibridismo. RBEP, Brasília, v. 101, n. 257, p. 79-98, jan./abr. 2020. Seção: Estudos.

Grupo Escolar Dom Benevides - educação na ditadura civil-militar Educação Moral e Cívica.

CARVALHO, Rosana Areal; SILVA, Fernanda Aparecida Oliveira Rodrigues; EVANGELISTA, Raquel Jesus. A disciplina Educação Moral e Cívica no Grupo Escolar Dom Benevides em Mariana/MG (1969-1975). RBEP, Brasília, v. 101, n. 258, p. 458-480, maio/ago. 2020. Seção: Estudos.

Higher education - quality - school effectiveness.

FERNANDES, Vivian Duarte Couto; MIRANDA, Gilberto José; ALEXANDER, Nicola. Value-added measure in higher education: a historical contextualization of Brazilian experience. RBEP, Brasília, v. 101, n. 259, p. 691-720, set./dez. 2020. Seção: Estudos.

História da educação - ensino superior - química.

SANTOS, Ademir Valdir dos; CUSTÓDIO, Renato da Silva. A serviço da Medicina: origem da disciplina de Química no Compêndio Histórico da Universidade de Coimbra (1771). RBEP, Brasília, v. 101, n. 257, p. 182-196, jan./abr. 2020. Seção: Estudos.

Identidade profissional - atualização de professores - educação básica. ROSSI, Fernanda; HUNGER, Dagmar. Identidade docente e formação continuada: um estudo à luz das teorias de Zygmunt Bauman e Claude Dubar. RBEP, Brasília, v. 101, n. 258, p. 313-336, maio/ago. 2020. Seção: Estudos. 
Identidade racial - análise da informação - sistema de cotas.

FREITAS, Matheus; SARMENTO, Rayza. As falas sobre a fraude: análise das notícias sobre casos e fraudes nas cotas raciais em universidades em Minas Gerais. RBEP, Brasília, v. 101, n. 258, p. 271-294, maio/ago. 2020. Seção: Estudos.

Ilustrações do livro didático - avaliação do livro didático - neuroeducação.

SILVA, Kleyfton Soares da; FONSECA, Laerte Silva da. Bases neuroeducativas do papel das ilustrações: uma proposta de análise de livro didático. RBEP, Brasília, v. 101, n. 257, p. 36-56, jan./abr. 2020. Seção: Estudos.

Instituição comunitária de ensino - educação superior - gestão mercantilização do ensino.

FIOREZE, Cristina. Gestão das IES privadas sem fins lucrativos diante dos tensionamentos da mercantilização da educação superior e o caso das universidades comunitárias regionais: a caminho do hibridismo. RBEP, Brasília, v. 101, n. 257, p. 79-98, jan./abr. 2020. Seção: Estudos.

Integração razão/ação/emoção - teoria Bioecológica do Desenvolvimento Humano - Teoria Histórico-Cultural - processo de ensino-aprendizagem.

SOUZA, Joelson Carvalho; HICKMANN, Adolfo Antonio; ASINELLI-LUZ, Araci; HICKMANN, Girlane Moura. A influência das emoções no aprendizado dos escolares. RBEP, Brasília, v. 101, n. 258, p. 382-403, maio/ago. 2020. Seção: Estudos.

Interculturalidade - alteridade - migração boliviana.

GONDIN, Janaina Silva; PINEZI, Ana Keila Mosca; MENEZES, Marilda Aparecida de. Alteridade e interculturalidade na escola: um estudo etnográfico sobre estudantes bolivianos em São Paulo. RBEP, Brasília, v. 101, n. 259, p. 607-626, set./dez. 2020. Seção: Estudos.

Interdisciplinaridade - colonialidade - práxis pedagógica.

RAMOS, Luiza Olivia Lacerda; FERREIRA, Rosilda Arruda. Sobre uma práxis interdisciplinar: aproximações e proposições conceituais. RBEP, Brasília, v. 101, n. 257, p. 197-216, jan./abr. 2020. Seção: Estudos.

Investigación - América Latina - educación superior - universidad.

CAREGNATO, Célia Elizabete; SANTIN, Dirce Maria; DEL VALLE, Dámian; TAKAYANAGUI, Axel Didriksson. Educación superior y universidad en América Latina: perspectivas temáticas para debates e investigaciones. RBEP, Brasília, v. 101, n. 259, p. 666-686, set./dez. 2020. Seção: Estudos.

Licenciatura - docência no ensino superior - metodologia.

ROCATELI, Adrielly; FRANCO, Sandra Aparecida Pires; GALVÃO, Rosangela Miola; CASAGRANDE, Fernanda Couto Guimarães. Trabalho pedagógico nos cursos de licenciatura da Universidade Estadual de Londrina: metodologias em questão. RBEP, Brasília, v. 101, n. 259, p. 752-770, set./dez. 2020.

Seção: Estudos. 
Mercantilização do ensino - educação superior - gestão - instituição comunitária de ensino.

FIOREZE, Cristina. Gestão das IES privadas sem fins lucrativos diante dos tensionamentos da mercantilização da educação superior e o caso das universidades comunitárias regionais: a caminho do hibridismo. RBEP, Brasília, v. 101, n. 257, p. 79-98, jan./abr. 2020. Seção: Estudos.

Memória - desempenho em matemática - funções executivas.

SANTANA, Alanny Nunes de; ROAZZI, Antonio; MELO, Monilly Ramos Araújo. Os três componentes executivos básicos e o desempenho matemático escolar. RBEP, Brasília, v. 101, n. 259, p. 649-609, set./dez. 2020. Seção: Estudos.

Metodologia de ensino - estratégia de aprendizagem - motivação do estudante.

HONÓRIO, Daniel Augusto; JESUS, Josiane Aparecida de; FIN, Gracielle; NODARI JUNIOR, Rudy José. Perfil motivacional, formas de estudo e satisfação com a vida de estudantes universitários. RBEP, Brasília, v. 101, n. 258, p. 420-435, maio/ago. 2020. Seção: Estudos.

Metodologia do ensino - ambiente virtual de aprendizagem - teorias de aprendizagem.

AGONÁCS, Nikoletta; MATOS, João Filipe. Os Cursos On-line Abertos e Massivos (Mooc) como ambientes heutagógicos. RBEP, Brasília, v. 101, n. 257, p. 17-35, jan./abr. 2020. Seção: Estudos.

Metodologia - licenciatura - docência no ensino superior.

ROCATELI, Adrielly; FRANCO, Sandra Aparecida Pires; GALVÃO, Rosangela Miola; CASAGRANDE, Fernanda Couto Guimarães. Trabalho pedagógico nos cursos de licenciatura da Universidade Estadual de Londrina: metodologias em questão. RBEP, Brasília, v. 101， n. 259, p. 752-770, set./dez. 2020. Seção: Estudos.

Migração boliviana - alteridade - interculturalidade.

GONDIN, Janaina Silva; PINEZI, Ana Keila Mosca; MENEZES, Marilda Aparecida de. Alteridade e interculturalidade na escola: um estudo etnográfico sobre estudantes bolivianos em São Paulo. RBEP, Brasília, v. 101, n. 259, p. 607-626, set./dez. 2020. Seção: Estudos.

Modelo de formação docente - curso de licenciatura - educação comparada.

CACHAPUZ, António Francisco; SHIGUNOV NETO, Alexandre; SILVA, André Coelho da. Formação inicial de professores de Física no Brasil e em Portugal: uma análise comparativa de modelos de formação. RBEP, Brasília, v. 101, n. 257, p. 146-163, jan./abr. 2020. Seção: Estudos.

Motivação do estudante - estratégia de aprendizagem - metodologia de ensino.

HONÓRIO, Daniel Augusto; JESUS, Josiane Aparecida de; FIN, Gracielle; NODARI JUNIOR, Rudy José. Perfil motivacional, formas de estudo e 
satisfação com a vida de estudantes universitários. RBEP, Brasília, v. 101, n. 258, p. 420-435, maio/ago. 2020. Seção: Estudos.

Neuroeducação - avaliação do livro didático - ilustrações do livro didático.

SILVA, Kleyfton Soares da; FONSECA, Laerte Silva da. Bases neuroeducativas do papel das ilustrações: uma proposta de análise de livro didático. RBEP, Brasília, v. 101, n. 257, p. 36-56, jan./abr. 2020. Seção: Estudos.

Nível cognitivo de dificuldade - Enade-Química - processo cognitivo. SILVA, Márcia Gorette Lima da; MAZZE, Fernanda. O que avalia a prova do Enade de Química?: Uma proposta de análise em termos de operações cognitivas. RBEP, Brasília, v. 101, n. 259, p. 721-751, set./dez. 2020. Seção: Estudos.

Parâmetros Curriculares Nacionais - Base Nacional Comum Curricular programa de alfabetização.

GUILLEN, Cássia Helena; MIGUEL, Maria Elisabeth Blanck. A alfabetização nos Parâmetros Curriculares Nacionais (PCN) e na Base Nacional Comum Curricular (BNCC): o que mudou de 1997 a 2017. RBEP, Brasília, v. 101, n. 259, p. 567-582, set./dez. 2020. Seção: Estudos.

Pedagogia - curso e currículo - políticas públicas em educação.

FERREIRA, Liliana Soares; MACHADO, Célia Tanajura; MARASCHIN, Mariglei Severo; DE TONI, Dulcineia Libraga Papalia. Políticas educacionais e os impactos sobre processos educativos nos cursos de pedagogia: uma análise. RBEP, Brasília, v. 101, n. 258, p. 295-312, maio/ago. 2020. Seção: Estudos.

Pesquisa da educação - ensino de arte - escola-parque.

VASCONCELOS, Rafaella Lira Silva dos Santos de; WIGGERS, Ingrid Dittrich. A arte nas escolas-parque de Brasília: concepções do trabalho pedagógico. RBEP, Brasília, v. 101, n. 259, p. 547-566, set./dez. 2020. Seção: Estudos.

Política ambiental - estudo de caso - prática de educação ambiental. FARIAS FILHO; Everaldo Nunes de; FARIAS, Carmen Roselaine de Oliveira. Duas décadas da Política Nacional de Educação Ambiental: percepções de professores no contexto de uma escola pública de Pernambuco. RBEP, Brasília, v. 101, n. 258, p. 481-502, maio/ago. 2020. Seção: Relatos de Experiência.

Políticas públicas - centro integrado de ensino - Enem.

NASCIMENTO, Matheus Monteiro; CAVALCANTI, Cláudio; OSTERMANN, Fernanda. Dez anos de instituição da Rede Federal de Educação Profissional, Científica e Tecnológica: o papel social dos institutos federais. RBEP, Brasília, v. 101, n. 257, p. 120-145, jan./abr. 2020. Seção: Estudos.

Políticas públicas em educação - curso e currículo - Pedagogia.

FERREIRA, Liliana Soares; MACHADO, Célia Tanajura; MARASCHIN, Mariglei Severo; DE TONI, Dulcineia Libraga Papalia. Políticas educacionais 
e os impactos sobre processos educativos nos cursos de pedagogia: uma análise. RBEP, Brasília, v. 101, n. 258, p. 295-312, maio/ago. 2020. Seção: Estudos.

Pós-graduação stricto sensu - educação física - formação de professores. TEIXEIRA, Fabiane Castilho; SOUZA, Juliano de; BROCH, Caroline; BARBOSA-RINALDI, Ieda Parra. Entre pesquisa e docência: notas sobre o projeto formativo stricto sensu em Educação Física. RBEP, Brasília, v. 101, n. 257, p. 164-181, jan./abr. 2020. Seção: Estudos.

Prática de educação ambiental - estudo de caso - política ambiental. FARIAS FILHO; Everaldo Nunes de; FARIAS, Carmen Roselaine de Oliveira. Duas décadas da Política Nacional de Educação Ambiental: percepções de professores no contexto de uma escola pública de Pernambuco. RBEP, Brasília, v. 101, n. 258, p. 481-502, maio/ago. 2020. Seção: Relatos de Experiência.

Prática pedagógica - análise linguística - formação de professores. SUASSUNA, Lívia. O ensino de análise linguística por estagiários da licenciatura em Letras. RBEP, Brasília, v. 101, n. 257, p. 57-78, jan./abr. 2020. Seção: Estudos.

Prática pedagógica - currículo - educação infantil.

DOMINICO, Eliane; LIRA, Aliandra Cristina Mesomo; SAITO, Heloisa Toshie Irie; YAEGASHI, Solange Franci Raimundo. Práticas pedagógicas na educação infantil: o currículo como instrumento de governo dos pequenos. RBEP, Brasília, v. 101, n. 257, p. 217-236, jan./abr. 2020. Seção: Estudos.

Praxema - praxiologia motriz - voleibol.

OLIVEIRA, Raquel Valente de; RIBAS, João Francisco Magno. O praxema no contexto esportivo: a linguagem expressa pelo corpo, a exemplo do Voleibol. RBEP, Brasília, v. 101, n. 258, p. 404-419, maio/ago. 2020. Seção: Estudos.

Praxiologia motriz - praxema - voleibol.

OLIVEIRA, Raquel Valente de; RIBAS, João Francisco Magno. O praxema no contexto esportivo: a linguagem expressa pelo corpo, a exemplo do Voleibol. RBEP, Brasília, v. 101, n. 258, p. 404-419, maio/ago. 2020. Seção: Estudos.

Práxis pedagógica - colonialidade - interdisciplinaridade.

RAMOS, Luiza Olivia Lacerda; FERREIRA, Rosilda Arruda. Sobre uma práxis interdisciplinar: aproximações e proposições conceituais. RBEP, Brasília, v. 101, n. 257, p. 197-216, jan./abr. 2020. Seção: Estudos.

Processo cognitivo - Enade-Química - nível cognitivo de dificuldade. SILVA, Márcia Gorette Lima da; MAZZÉ, Fernanda. O que avalia a prova do Enade de Química?: Uma proposta de análise em termos de operações cognitivas. RBEP, Brasília, v. 101, n. 259, p. 721-751, set./dez. 2020. Seção: Estudos. 
Processo de ensino-aprendizagem - teoria Bioecológica do Desenvolvimento Humano - Teoria Histórico-Cultural - integração razão/ação/emoção.

SOUZA, Joelson Carvalho; HICKMANN, Adolfo Antônio; ASINELLI-LUZ, Araci; HICKMANN, Girlane Moura. A influência das emoções no aprendizado dos escolares. RBEP, Brasília, v. 101, n. 258, p. 382-403, maio/ago. 2020. Seção: Estudos.

Produção científica - artigo científico - concepção de escrita.

SILVA, Elizabeth Maria da; SILVA, Maria Ariane Santos Amaro da; CUNHA, Raquel Laurentino; BRITO, Júlia Juliêta Silva de. O que é um "bom" artigo científico? Concepções de estudantes do curso de Engenharia Elétrica. RBEP, Brasília, v. 101, n. 259, p. 771-786, set./dez. 2020. Seção: Estudos.

Professores - análise de correspondência - análise fatorial autoeficácia - satisfação no trabalho.

FERREIRA, Enizete Andrade; RAMOS, Maely Ferreira Holanda; RAMOS, Edson Marcos Leal Soares; COUTO, Andréa Lobato. Autoeficácia, satisfação no trabalho, aspectos sociodemográficos e condições de trabalho de docentes-alunos do PARFOR. RBEP, Brasília, v. 101, n. 258, p. 337-358, maio/ago. 2020. Seção: Estudos.

Programa de alfabetização - Base Nacional Comum Curricular Parâmetros Curriculares Nacionais.

GUILLEN, Cássia Helena; MIGUEL, Maria Elisabeth Blanck. A alfabetização nos Parâmetros Curriculares Nacionais (PCN) e na Base Nacional Comum Curricular (BNCC): o que mudou de 1997 a 2017. RBEP, Brasília, v. 101, n. 259, p. 567-582, set./dez. 2020. Seção: Estudos.

Quality - higher education - school effectiveness.

FERNANDES, Vivian Duarte Couto; MIRANDA, Gilberto José; ALEXANDER, Nicola. Value-added measure in higher education: a historical contextualization of Brazilian experience. RBEP, Brasília, v. 101, n. 259, p. 691-720, set./dez. 2020. Seção: Estudos.

Química - ensino superior - história da educação.

SANTOS, Ademir Valdir dos; CUSTÓDIO, Renato da Silva. A serviço da Medicina: origem da disciplina de Química no Compêndio Histórico da Universidade de Coimbra (1771). RBEP, Brasília, v. 101, n. 257, p. 182-196, jan./abr. 2020. Seção: Estudos.

Rede Certific - certificação de saberes docentes - educação profissional formação dos profissionais da educação.

FASSINA, Ana Paula; WOLLINGER, Paulo; ALLAIN, Olivier. Certificação de saberes docentes na educação profissional: construção de um projetopiloto. RBEP, Brasília, v. 101, n. 259, p. 787-809, set./dez. 2020. Seção:

Relatos de Experiência. 
Relatório de pesquisa - avaliação de desempenho discente - Educação Física.

BARROS, João Luiz da Costa; CAMPOS, Márcia Zendron de; TEIXEIRA, Denilson de Castro; CABRAL, Breno Guilherme de Araujo Tinoco. Reflexões sobre o nível de conhecimentos específicos dos estudantes de licenciatura em Educação Física no Enade 2014. RBEP, Brasília, v. 101, n. 257, p. 99-119, jan./abr. 2020. Seção: Estudos.

Representação social - docência - educação compensatória. ROSSO, Ademir José; SILVA, Bruna Emilyn da; OLIVEIRA, Vânia Katzenwadel de; SANTOS, Franciely Ribeiro dos. Representações sociais de trabalhadores com baixa escolaridade sobre o trabalho docente. RBEP, Brasília, v. 101, n. 258, p. 359-381, maio/ago. 2020. Seção: Estudos.

Satisfação no trabalho - análise de correspondência - análise fatorial - autoeficácia - professores.

FERREIRA, Enizete Andrade; RAMOS, Maely Ferreira Holanda; RAMOS, Edson Marcos Leal Soares; COUTO, Andréa Lobato. Autoeficácia, satisfação no trabalho, aspectos sociodemográficos e condições de trabalho de docentes-alunos do PARFOR. RBEP, Brasília, v. 101, n. 258, p. 337-358, maio/ago. 2020. Seção: Estudos.

Saúde e educação - educação superior - evidência científica.

FERRAZ, Lucimare; SCHNEIDER, Luana Roberta; PEREIRA, Rui Pedro Gomes; PEREIRA, Altamiro Manuel Rodrigues Costa. Ensino e aprendizagem da prática baseada em evidências nos cursos de Enfermagem e Medicina. RBEP, Brasília, v. 101, n. 257, p. 237-250, jan./abr. 2020. Seção: Relatos de Experiência.

School effectiveness - higher education - quality.

FERNANDES, Vivian Duarte Couto; MIRANDA, Gilberto José; ALEXANDER, Nicola. Value-added measure in higher education: a historical contextualization of Brazilian experience. RBEP, Brasília, v. 101, n. 259, p. 691-720, set./dez. 2020. Seção: Estudos.

Sistema de cotas - análise da informação - identidade racial.

FREITAS, Matheus; SARMENTO, Rayza. As falas sobre a fraude: análise das notícias sobre casos e fraudes nas cotas raciais em universidades em Minas Gerais. RBEP, Brasília, v. 101, n. 258, p. 271-294, maio/ago. 2020. Seção: Estudos.

Tecnologia educacional - cultura digital - emoções - estudos socioculturais.

BROCHADO, Eliana Alice; HORNINK, Gabriel Gerber. Emoções experienciadas no processo de construção de narrativas digitais no Scratch. RBEP, Brasília, v. 101, n. 259, p. 627-648, set./dez. 2020. Seção: Estudos. 
Teoria Bioecológica do Desenvolvimento Humano - Teoria Histórico-Cultural - integração razão/ação/emoção - processo de ensino-aprendizagem.

SOUZA, Joelson Carvalho; HICKMANN, Adolfo Antonio; ASINELLI-LUZ, Araci; HICKMANN, Girlane Moura. A influência das emoções no aprendizado dos escolares. RBEP, Brasília, v. 101, n. 258, p. 382-403, maio/ago. 2020. Seção: Estudos.

Teoria Histórico-Cultural - Teoria Bioecológica do Desenvolvimento Humano - integração razão/ação/emoção - processo de ensino-aprendizagem.

SOUZA, Joelson Carvalho; HICKMANN, Adolfo Antonio; ASINELLI-LUZ, Araci; HICKMANN, Girlane Moura. A influência das emoções no aprendizado dos escolares. RBEP, Brasília, v. 101, n. 258, p. 382-403, maio/ago. 2020. Seção: Estudos.

Teorias de aprendizagem - ambiente virtual de aprendizagem metodologia do ensino.

AGONÁCS, Nikoletta; MATOS, João Filipe. Os Cursos On-line Abertos e Massivos (Mooc) como ambientes heutagógicos. RBEP, Brasília, v. 101, n. 257, p. 17-35, jan./abr. 2020. Seção: Estudos.

Universidad - América Latina - educación superior - investigación.

CAREGNATO, Célia Elizabete; SANTIN, Dirce Maria; DEL VALLE, Dámian; TAKAYANAGUI, Axel Didriksson. Educación superior y universidad en América Latina: perspectivas temáticas para debates e investigaciones. RBEP, Brasília, v. 101, n. 259, p. 670-690, set./dez. 2020. Seção: Estudos.

Voleibol - praxema - praxiologia motriz.

OLIVEIRA, Raquel Valente de; RIBAS, João Francisco Magno. O praxema no contexto esportivo: a linguagem expressa pelo corpo, a exemplo do Voleibol. RBEP, Brasília, v. 101, n. 258, p. 404-419, maio/ago. 2020. Seção: Estudos. 


\section{ÍNDICE DE AUTORES RBEP}

AGONÁCS, Nikoletta; MATOS, João Filipe. Os Cursos On-line Abertos e Massivos (Mooc) como ambientes heutagógicos. RBEP, Brasília, v. 101, n. 257, p. 17-35, jan./abr. 2020. Seção: Estudos.

ALEXANDER, Nicola; FERNANDES, Vivian Duarte Couto; MIRANDA, Gilberto José; Value-added measures in higher education: a historical contextualization of Brazilian experiences. RBEP, Brasília, v. 101, n. 259, 691-720, set./dez. 2020. Seção: Estudos.

ALLAIN, Olivier; FASSINA, Ana Paula; WOLLINGER, Paulo. Certificação de saberes docentes na educação profissional: construção de um projetopiloto. RBEP, Brasília, v. 101, n. 259, p. 787-809, set./dez. 2020. Seção: Relatos de Experiência.

ASINELLI-LUZ, Araci; SOUZA, Joelson Carvalho; HICKMANN, Adolfo Antonio; HICKMANN, Girlane Moura. A influência das emoções no aprendizado dos escolares. RBEP, Brasília, v. 101, n. 258, p. 382-403, maio/ ago. 2020. Seção: Estudos.

BARBOSA-RINALDI, Ieda Parra; TEIXEIRA, Fabiane Castilho; SOUZA, Juliano de; BROCH, Caroline. Entre pesquisa e docência: notas sobre o projeto formativo stricto sensu em Educação Física. RBEP, Brasília, v. 101, n. 257, p. 164-181, jan./abr. 2020. Seção: Estudos. 
BARROS, João Luiz da Costa; CAMPOS, Márcia Zendron de; TEIXEIRA, Denilson de Castro; CABRAL, Breno Guilherme de Araujo Tinoco. Reflexões sobre o nível de conhecimentos específicos dos estudantes de licenciatura em Educação Física no Enade 2014. RBEP, Brasília, v. 101, n. 257, p. 99-119, jan./abr. 2020. Seção: Estudos.

BRITO, Júlia Juliêta Silva de; SILVA, Elizabeth Maria da; SILVA, Maria Ariane Santos Amaro da; CUNHA, Raquel Laurentino. O que é um "bom" artigo científico? Concepções de estudantes do curso de Engenharia Elétrica. RBEP, Brasília, v. 101, n. 259, p. 771-786, set./dez. 2020. Seção: Estudos.

BROCH, Caroline; TEIXEIRA, Fabiane Castilho; SOUZA, Juliano de; BARBOSA-RINALDI, Ieda Parra. Entre pesquisa e docência: notas sobre o projeto formativo stricto sensu em Educação Física. RBEP, Brasília, v. 101, n. 257, p. 164-181, jan./abr. 2020. Seção: Estudos.

BROCHADO, Eliana Alice; HORNINK, Gabriel Gerber. Emoções experienciadas no processo de construção de narrativas digitais no Scratch. RBEP, Brasília, v. 101, n. 259, p. 627-648, set./dez. 2020. Seção: Estudos.

CABRAL, Breno Guilherme de Araujo Tinoco; BARROS, João Luiz da Costa; CAMPOS, Márcia Zendron de; TEIXEIRA, Denilson de Castro. Reflexões sobre o nível de conhecimentos específicos dos estudantes de licenciatura em Educação Física no Enade 2014. RBEP, Brasília, v. 101, n. 257, p. 99-119, jan./abr. 2020. Seção: Estudos.

CACHAPUZ, António Francisco; SHIGUNOV NETO, Alexandre; SILVA, André Coelho da. Formação inicial de professores de Física no Brasil e em Portugal: uma análise comparativa de modelos de formação. RBEP, Brasília, v. 101, n. 257, p. 146-163, jan./abr. 2020. Seção: Estudos.

CAMPOS, Márcia Zendron de; BARROS, João Luiz da Costa; TEIXEIRA, Denilson de Castro; CABRAL, Breno Guilherme de Araujo Tinoco. Reflexões sobre o nível de conhecimentos específicos dos estudantes de licenciatura em Educação Física no Enade 2014. RBEP, Brasília, v. 101, n. 257, p. 99-119, jan./abr. 2020. Seção: Estudos.

CAREGNATO, Célia Elizabete; SANTIN, Dirce Maria; DEL VALLE, Dámian; TAKAYANAGUI, Axel Didriksson. Educación superior y universidad en América Latina: perspectivas temáticas para debates e investigaciones. RBEP, Brasília, v. 101, n. 259, p.670-690, set./dez. 2020. Seção: Estudos.

CARVALHO, Rosana Areal; SILVA, Fernanda Aparecida Oliveira Rodrigues; EVANGELISTA, Raquel Jesus. A disciplina Educação Moral e Cívica no Grupo Escolar Dom Benevides em Mariana/MG (1969-1975). RBEP, Brasília, v. 101, n. 258, p. 458-479, maio/ago. 2020. Seção: Estudos.

CASAGRANDE, Fernanda Couto Guimarães; ROCATELI, Adrielly; FRANCO, Sandra Aparecida Pires; GALVÃO, Rosangela Miola. Trabalho pedagógico nos cursos de licenciatura da Universidade Estadual de Londrina: 
metodologias em questão. RBEP, Brasília, v. 101, n. 259, p. 752-770, set./dez. 2020. Seção: Estudos.

CAVALCANTI, Cláudio; NASCIMENTO, Matheus Monteiro; OSTERMANN, Fernanda. Dez anos de instituição da Rede Federal de Educação Profissional, Científica e Tecnológica: o papel social dos institutos federais. RBEP, Brasília, v. 101, n. 257, p. 120-145, jan./abr. 2020. Seção: Estudos.

GUILLEN, Cássia Helena; MIGUEL, Maria Elisabeth Blanck. A alfabetização nos Parâmetros Curriculares Nacionais (PCN) e na Base Nacional Comum Curricular (BNCC): o que mudou de 1997 a 2017. RBEP, Brasília, v. 101, n. 259, p. 567-582, set./dez. 2020. Seção: Estudos.

COUTO, Andréa Lobato; FERREIRA, Enizete Andrade; RAMOS, Maely Ferreira Holanda; RAMOS, Edson Marcos Leal Soares. Autoeficácia, satisfação no trabalho, aspectos sociodemográficos e condições de trabalho de docentes-alunos do PARFOR. RBEP, Brasília, v. 101, n. 258, p. 337-358, maio/ago. 2020. Seção: Estudos.

CUNHA, Raquel Laurentino; SILVA, Elizabeth Maria da; SILVA, Maria Ariane Santos Amaro da; BRITO, Júlia Juliêta Silva de. O que é um "bom" artigo científico? Concepções de estudantes do curso de engenharia elétrica. RBEP, Brasília, v. 101, n. 259, p. 771-786, set./dez. 2020. Seção: Estudos.

CUSTÓDIO, Renato da Silva; SANTOS, Ademir Valdir dos. A serviço da Medicina: origem da disciplina de Química no Compêndio Histórico da Universidade de Coimbra (1771). RBEP, Brasília, v. 101, n. 257, p. 182-196, jan./abr. 2020. Seção: Estudos.

DE TONI, Dulcineia Libraga Papalia; FERREIRA, Liliana Soares; MACHADO, Célia Tanajura; MARASCHIN, Mariglei Severo. Políticas educacionais e os impactos sobre processos educativos nos cursos de pedagogia: uma análise. RBEP, Brasília, v. 101, n. 258, p. 295-312, maio/ago. 2020. Seção: Estudos.

DEL VALLE, Dámian; CAREGNATO, Célia Elizabete; SANTIN, Dirce Maria; TAKAYANAGUI, Axel Didriksson. Educación superior y universidad en América Latina: perspectivas temáticas para debates e investigaciones. RBEP, Brasília, v. 101, n. 259, p. 670-690, set./dez. 2020. Seção: Estudos.

DIÓGENES, Camila Gomes; VALOYES, Angie Yirlesa Valoyes; EUZEBIO, Umberto. Implementación de la competencia 10 de la Base Nacional Común Curricular en Brasil: un análisis desde el concepto de Ciudadanía Global de la Agenda 2030. RBEP, Brasília, v. 101, n. 259, p. 583-606, set./dez. 2020. Seção: Estudos.

DOMINICO, Eliane; LIRA, Aliandra Cristina Mesomo; SAITO, Heloisa Toshie Irie; YAEGASHI, Solange Franci Raimundo. Práticas pedagógicas na educação infantil: o currículo como instrumento de governo dos pequenos. RBEP, Brasília, v. 101, n. 257, p. 217-236, jan./abr. 2020. Seção: Estudos. 
EUZEBIO, Umberto; DIÓGENES, Camila Gomes; VALOYES, Angie Yirlesa Valoyes. Implementación de la competencia 10 de la Base Nacional Común Curricular en Brasil: un análisis desde el concepto de Ciudadanía Global de la Agenda 2030. RBEP, Brasília, v. 101, n. 259, p. 583-606, set./dez. 2020. Seção: Estudos.

EVANGELISTA, Raquel Jesus; CARVALHO, Rosana Areal; SILVA, Fernanda Aparecida Oliveira Rodrigues. A disciplina Educação Moral e Cívica no Grupo Escolar Dom Benevides em Mariana/MG (1969-1975). RBEP, Brasília, v. 101, n. 258, p. 458-479, maio/ago. 2020. Seção: Estudos.

FARIAS, Carmen Roselaine de Oliveira; FARIAS FILHO, Everaldo Nunes de. Duas décadas da Política Nacional de Educação Ambiental: percepções de professores no contexto de uma escola pública de Pernambuco. RBEP, Brasília, v. 101, n. 258, p. 481-502, maio/ago. 2020. Seção: Relatos de Experiência.

FARIAS FILHO, Everaldo Nunes de; FARIAS, Carmen Roselaine de Oliveira. Duas décadas da Política Nacional de Educação Ambiental: percepções de professores no contexto de uma escola pública de Pernambuco. RBEP, Brasília, v. 101, n. 258, p. 481-502, maio/ago. 2020. Seção: Relatos de Experiência.

FASSINA, Ana Paula; WOLLINGER, Paulo; ALLAIN, Olivier. Certificação de saberes docentes na educação profissional: construção de um projetopiloto. RBEP, Brasília, v. 101, n. 259, p. 787-809, set./dez. 2020. Seção: Relatos de Experiência.

FERNANDES, Vivian Duarte Couto; MIRANDA, Gilberto José; ALEXANDER, Nicola. Value-added measures in higher education: a historical contextualization of Brazilian experiences. RBEP, Brasília, v. 101, n. 259, p. 687-716, set./dez. 2020. Seção: Estudos.

FERRAZ, Lucimare; SCHNEIDER, Luana Roberta; PEREIRA, Rui Pedro Gomes; PEREIRA, Altamiro Manuel Rodrigues Costa. Ensino e aprendizagem da prática baseada em evidências nos cursos de Enfermagem e Medicina. RBEP, Brasília, v. 101, n. 257, p. 237-249, jan./abr. 2020. Seção: Relatos de Experiência.

FERREIRA, Enizete Andrade; RAMOS, Maely Ferreira Holanda; RAMOS, Edson Marcos Leal Soares; COUTO, Andréa Lobato. Autoeficácia, satisfação no trabalho, aspectos sociodemográficos e condições de trabalho de docentes-alunos do PARFOR. RBEP, Brasília, v. 101, n. 258, p. 337-358, maio/ago. 2020. Seção: Estudos.

FERREIRA, Liliana Soares; MACHADO, Célia Tanajura; MARASCHIN, Mariglei Severo; DE TONI, Dulcineia Libraga Papalia. Políticas educacionais e os impactos sobre processos educativos nos cursos de pedagogia: uma análise. RBEP, Brasília, v. 101, n. 258, p. 295-312, maio/ago. 2020. Seção: Estudos. 
FERREIRA, Rosilda Arruda; RAMOS, Luiza Olivia Lacerda. Sobre uma práxis interdisciplinar: aproximações e proposições conceituais. RBEP, Brasília, v. 101, n. 257, p. 197-216, jan./abr. 2020. Seção: Estudos.

FIN, Gracielle; HONÓRIO, Daniel Augusto; JESUS, Josiane Aparecida de; NODARI JÚNIOR, Rudy José. Perfil motivacional, formas de estudo e satisfação de estudantes universitários com a vida. RBEP, Brasília, v. 101, n. 258, p. 420-435, maio/ago. 2020. Seção: Estudos.

FIOREZE, Cristina. Gestão das IES privadas sem fins lucrativos diante dos tensionamentos da mercantilização da educação superior e o caso das universidades comunitárias regionais: a caminho do hibridismo. RBEP, Brasília, v. 101, n. 257, p. 79-98, jan./abr. 2020. Seção: Estudos.

FONSECA, Laerte Silva da; SILVA, Kleyfton Soares da. Bases neuroeducativas do papel das ilustrações: uma proposta de análise de livro didático. RBEP, Brasília, v. 101, n. 257, p. 36-56, jan./abr. 2020. Seção: Estudos.

FRANCO, Sandra Aparecida Pires; ROCATELI, Adrielly; GALVÃO, Rosangela Miola; CASAGRANDE, Fernanda Couto Guimarães. Trabalho pedagógico nos cursos de licenciatura da Universidade Estadual de Londrina: metodologias em questão. RBEP, Brasília, v. 101, n. 259, p. 752-770, set./dez. 2020. Seção: Estudos.

FREITAS, Matheus; SARMENTO, Rayza. As falas sobre a fraude: análise das notícias sobre casos e fraudes nas cotas raciais em universidades em Minas Gerais. RBEP, Brasília, v. 101, n. 258, p. 271-294, maio/ago. 2020. Seção: Estudos.

GALVÃO, Rosangela Miola; ROCATELI, Adrielly; FRANCO, Sandra Aparecida Pires; CASAGRANDE, Fernanda Couto Guimarães. Trabalho pedagógico nos cursos de licenciatura da Universidade Estadual de Londrina: metodologias em questão. RBEP, Brasília, v. 101, n. 259, p. 752-770, set./dez. 2020. Seção: Estudos.

GONDIN, Janaina Silva; PINEZI, Ana Keila Mosca; MENEZES, Marilda Aparecida de. Alteridade e interculturalidade na escola: um estudo etnográfico sobre estudantes bolivianos em São Paulo. RBEP, Brasília, v. 101, n. 259, p. 607-626, set./dez. 2020. Seção: Estudos.

GUILLEN, Cássia Helena; MIGUEL, Maria Elisabeth Blanck. A alfabetização nos Parâmetros Curriculares Nacionais (PCN) e na Base Nacional Comum Curricular (BNCC): o que mudou de 1997 a 2017. RBEP, Brasília, v. 101, n. 259, p. 567-582 set./dez. 2020. Seção: Estudos.

HICKMANN, Adolfo Antonio; SOUZA, Joelson Carvalho; ASINELLI-LUZ, Araci; HICKMANN, Girlane Moura. A influência das emoções no aprendizado dos escolares. RBEP, Brasília, v. 101, n. 258, p. 382-403, maio/ago. 2020. Seção: Estudos. 
HICKMANN, Girlane Moura; SOUZA, Joelson Carvalho; HICKMANN, Adolfo Antonio; ASINELLI-LUZ, Araci. A influência das emoções no aprendizado dos escolares. RBEP, Brasília, v. 101, n. 258, p. 382-403, maio/ago. 2020. Seção: Estudos.

HONÓRIO, Daniel Augusto; JESUS, Josiane Aparecida de; FIN, Gracielle; NODARI JÚNIOR, Rudy José. Perfil motivacional, formas de estudo e satisfação de estudantes universitários com a vida. RBEP, Brasília, v. 101, n. 258, p. 420-435, maio/ago. 2020. Seção: Estudos.

HORNINK, Gabriel Gerber; BROCHADO, Eliana Alice. Emoções experienciadas no processo de construção de narrativas digitais no Scratch. RBEP, Brasília, v. 101, n. 259, p. 627-648, set./dez. 2020. Seção: Estudos.

HUNGER, Dagmar; ROSSI, Fernanda. Identidade docente e formação continuada: um estudo à luz das teorias de Zygmunt Bauman e Claude Dubar. RBEP, Brasília, v. 101, n. 258, p. 313-336, maio/ago. 2020. Seção: Estudos.

JESUS, Denise Meyrelles de; VIEIRA, Alexandro Braga; LIMA, Jovenildo da Cruz; MARIANO, Clayde Aparecida Belo da Silva. As contribuições de Meirieu para a formação continuada de professores e a adoção de práticas pedagógicas inclusivas. RBEP, Brasília, v. 101, n. 258, p. 503-522, maio/ago. 2020. Seção: Relatos de Experiência.

JESUS, Josiane Aparecida de; HONÓRIO, Daniel Augusto; FIN, Gracielle; NODARI JÚNIOR, Rudy José. Perfil motivacional, formas de estudo e satisfação de estudantes universitários com a vida. RBEP, Brasília, v. 101, n. 258, p. 420-435, maio/ago. 2020. Seção: Estudos.

LAVERDE, Albenise; OLIVEIRA, Cláudia Terezinha de Andrade. Os espaços experimentais das escolas públicas de arquitetura do Brasil: realidade ou utopia? RBEP, Brasília, v. 101, n. 258, p. 436-457, maio/ago. 2020. Seção: Estudos.

LIMA, Jovenildo da Cruz; VIEIRA, Alexandro Braga; JESUS, Denise Meyrelles de; MARIANO, Clayde Aparecida Belo da Silva. As contribuições de Meirieu para a formação continuada de professores e a adoção de práticas pedagógicas inclusivas. RBEP, Brasília, v. 101, n. 258, p. 503-522, maio/ago. 2020. Seção: Relatos de Experiência.

LIRA, Aliandra Cristina Mesomo; DOMINICO, Eliane; SAITO, Heloisa Toshie Irie; YAEGASHI, Solange Franci Raimundo. Práticas pedagógicas na educação infantil: o currículo como instrumento de governo dos pequenos. RBEP, Brasília, v. 101, n. 257, p. 217-236, jan./abr. 2020. Seção: Estudos.

MACHADO, Célia Tanajura; FERREIRA, Liliana Soares; MARASCHIN, Mariglei Severo; DE TONI, Dulcineia Libraga Papalia. Políticas educacionais e os impactos sobre processos educativos nos cursos de pedagogia: uma análise. RBEP, Brasília, v. 101, n. 258, p. 295-312, maio/ago. 2020. Seção: Estudos. 
MARASCHIN, Mariglei Severo; FERREIRA, Liliana Soares; MACHADO, Célia Tanajura; DE TONI, Dulcineia Libraga Papalia. Políticas educacionais e os impactos sobre processos educativos nos cursos de pedagogia: uma análise. RBEP, Brasília, v. 101, n. 258, p. 295-312, maio/ago. 2020. Seção: Estudos.

MARIANO, Clayde Aparecida Belo da Silva; VIEIRA, Alexandro Braga; JESUS, Denise Meyrelles de; LIMA, Jovenildo da Cruz. As contribuições de Meirieu para a formação continuada de professores e a adoção de práticas pedagógicas inclusivas. RBEP, Brasília, v. 101, n. 258, p. 503-522, maio/ago. 2020. Seção: Relatos de Experiência.

MATOS, João Filipe; AGONÁCS, Nikoletta. Os Cursos On-line Abertos e Massivos (Mooc) como ambientes heutagógicos. RBEP, Brasília, v. 101, n. 257, p. 17-35, jan./abr. 2020. Seção: Estudos.

MAZZÉ, Fernanda; SILVA, Márcia Gorette Lima da. O que avalia a prova do Enade de Química? Uma proposta de análise em termos de operações cognitivas. RBEP, Brasília, v. 101, n. 259, p. 721-751, set./dez. 2020. Seção: Estudos.

MELO, Monilly Ramos Araújo; SANTANA, Alanny Nunes de; ROAZZI, Antonio. Os três componentes executivos básicos e o desempenho matemático escolar. RBEP, Brasília, v. 101, n. 259, p. 649-669, set./dez. 2020. Seção: Estudos.

MENEZES, Marilda Aparecida de; GONDIN, Janaina Silva; PINEZI, Ana Keila Mosca. Alteridade e interculturalidade na escola: um estudo etnográfico sobre estudantes bolivianos em São Paulo. RBEP, Brasília, v. 101, n. 259, p. 607-626, set./dez. 2020. Seção: Estudos.

MIGUEL, Maria Elisabeth Blanck; GUILLEN, Cássia Helena. A alfabetização nos Parâmetros Curriculares Nacionais (PCN) e na Base Nacional Comum Curricular (BNCC): o que mudou de 1997 a 2017. RBEP, Brasília, v. 101, n. 259, p. 567-582, set./dez. 2020. Seção: Estudos.

MIRANDA, Gilberto José; FERNANDES, Vivian Duarte Couto; ALEXANDER, Nicola. Value-added measures in higher education: a historical contextualization of Brazilian experiences. RBEP, Brasília, v. 101, n. 259, p. 687-716, set./dez. 2020. Seção: Estudos.

NASCIMENTO, Matheus Monteiro; CAVALCANTI, Cláudio; OSTERMANN, Fernanda. Dez anos de instituição da Rede Federal de Educação Profissional, Científica e Tecnológica: o papel social dos institutos federais. RBEP, Brasília, v. 101, n. 257, p. 120-145, jan./abr. 2020. Seção: Estudos.

NODARI JÚNIOR, Rudy José; HONÓRIO, Daniel Augusto; JESUS, Josiane Aparecida de; FIN, Gracielle. Perfil motivacional, formas de estudo e satisfação de estudantes universitários com a vida. RBEP, Brasília, v. 101, n. 258, p. 420-435, maio/ago. 2020. Seção: Estudos. 
OLIVEIRA, Cláudia Terezinha de Andrade; LAVERDE, Albenise. Os espaços experimentais das escolas públicas de arquitetura do Brasil: realidade ou utopia? RBEP, Brasília, v. 101, n. 258, p. 436-457, maio/ago. 2020. Seção: Estudos.

OLIVEIRA, Raquel Valente de; RIBAS, João Francisco Magno. O praxema no contexto esportivo: a linguagem expressa pelo corpo, a exemplo do Voleibol. RBEP, Brasília, v. 101, n. 258, p. 404-419, maio/ago. 2020. Seção: Estudos.

OLIVEIRA, Vânia Katzenwadel de; ROSSO, Ademir José; SILVA, Bruna Emilyn da; SANTOS, Franciely Ribeiro dos. Representações sociais de trabalhadores com baixa escolaridade sobre o trabalho docente. RBEP, Brasília, v. 101, n. 258, p. 359-381, maio/ago. 2020. Seção: Estudos.

OSTERMANN, Fernanda; NASCIMENTO, Matheus Monteiro; CAVALCANTI, Cláudio. Dez anos de instituição da Rede Federal de Educação Profissional, Científica e Tecnológica: o papel social dos institutos federais. RBEP, Brasília, v. 101, n. 257, p. 120-145, jan./abr. 2020. Seção: Estudos.

PEREIRA, Altamiro Manuel Rodrigues Costa; FERRAZ, Lucimare; SCHNEIDER, Luana Roberta; PEREIRA, Rui Pedro Gomes. Ensino e aprendizagem da prática baseada em evidências nos cursos de Enfermagem e Medicina. RBEP, Brasília, v. 101, n. 257, p. 237-249, jan./abr. 2020. Seção: Relatos de Experiência.

PEREIRA, Rui Pedro Gomes; FERRAZ, Lucimare; SCHNEIDER, Luana Roberta; PEREIRA, Altamiro Manuel Rodrigues Costa. Ensino e aprendizagem da prática baseada em evidências nos cursos de Enfermagem e Medicina. RBEP, Brasília, v. 101, n. 257, p. 237-249, jan./abr. 2020. Seção: Relatos de Experiência.

PINEZI, Ana Keila Mosca; GONDIN, Janaina Silva; MENEZES, Marilda Aparecida de. Alteridade e interculturalidade na escola:um estudo etnográfico sobre estudantes bolivianos em São Paulo. RBEP, Brasília, v. 101, n. 259, p. 607-626, set./dez. 2020. Seção: Estudos.

RAMOS, Edson Marcos Leal Soares; FERREIRA, Enizete Andrade; RAMOS, Maely Ferreira Holanda; COUTO, Andréa Lobato. Autoeficácia, satisfação no trabalho, aspectos sociodemográficos e condições de trabalho de docentesalunos do PARFOR. RBEP, Brasília, v. 101, n. 258, p. 337-358, maio/ago. 2020. Seção: Estudos.

RAMOS, Luiza Olivia Lacerda; FERREIRA, Rosilda Arruda. Sobre uma práxis interdisciplinar: aproximações e proposições conceituais. RBEP, Brasília, v. 101, n. 257, p. 197-216, jan./abr. 2020. Seção: Estudos.

RAMOS, Maely Ferreira Holanda; FERREIRA, Enizete Andrade; RAMOS, Edson Marcos Leal Soares; COUTO, Andréa Lobato. Autoeficácia, satisfação no trabalho, aspectos sociodemográficos e condições de trabalho de 
docentes-alunos do PARFOR. RBEP, Brasília, v. 101, n. 258, p. 337-358, maio/ago. 2020. Seção: Estudos.

RIBAS, João Francisco Magno; OLIVEIRA, Raquel Valente de. O praxema no contexto esportivo: a linguagem expressa pelo corpo, a exemplo do Voleibol. RBEP, Brasília, v. 101, n. 258, p. 404-419, maio/ago. 2020. Seção: Estudos.

ROAZZI, Antonio; SANTANA, Alanny Nunes de; MELO, Monilly Ramos Araújo. Os três componentes executivos básicos e o desempenho matemático escolar. RBEP, Brasília, v. 101, n. 259, p. 649-669, set./dez. 2020. Seção: Estudos.

ROCATELI, Adrielly; FRANCO, Sandra Aparecida Pires; GALVÃO, Rosangela Miola; CASAGRANDE, Fernanda Couto Guimarães. Trabalho pedagógico nos cursos de licenciatura da Universidade Estadual de Londrina: metodologias em questão. RBEP, Brasília, v. 101, n. 259, p.752-770, set./dez. 2020. Seção: Estudos.

ROSSI, Fernanda; HUNGER, Dagmar. Identidade docente e formação continuada: um estudo à luz das teorias de Zygmunt Bauman e Claude Dubar. RBEP, Brasília, v. 101, n. 258, p. 313-336, maio/ago. 2020. Seção: Estudos.

ROSSO, Ademir José; SILVA, Bruna Emilyn da; OLIVEIRA, Vânia Katzenwadel de; SANTOS, Franciely Ribeiro dos. Representações sociais de trabalhadores com baixa escolaridade sobre o trabalho docente. RBEP, Brasília, v. 101, n. 258, p. 359-381, maio/ago. 2020. Seção: Estudos.

SAITO, Heloisa Toshie Irie; DOMINICO, Eliane; LIRA, Aliandra Cristina Mesomo; YAEGASHI, Solange Franci Raimundo. Práticas pedagógicas na educação infantil: o currículo como instrumento de governo dos pequenos. RBEP, Brasília, v. 101, n. 257, p. 217-236, jan./abr. 2020. Seção: Estudos.

SANTANA, Alanny Nunes de; ROAZZI, Antonio; MELO, Monilly Ramos Araújo. Os três componentes executivos básicos e o desempenho matemático escolar. RBEP, Brasília, v. 101, n. 259, p. 649-669, set./dez. 2020. Seção: Estudos.

SANTIN, Dirce Maria; CAREGNATO, Célia Elizabete; DEL VALLE, Dámian; TAKAYANAGUI, Axel Didriksson. Educación superior y universidad en América Latina: perspectivas temáticas para debates e investigaciones. RBEP, Brasília, v. 101, n. 259, p. 670-690, set./dez. 2020. Seção: Estudos.

SANTOS, Ademir Valdir dos; CUSTÓDIO, Renato da Silva. A serviço da Medicina: origem da disciplina de Química no Compêndio Histórico da Universidade de Coimbra (1771). RBEP, Brasília, v. 101, n. 257, p. 182-196, jan./abr. 2020. Seção: Estudos.

SANTOS, Franciely Ribeiro dos; ROSSO, Ademir José; SILVA, Bruna Emilyn da; OLIVEIRA, Vânia Katzenwadel de. Representações sociais de 
trabalhadores com baixa escolaridade sobre o trabalho docente. RBEP, Brasília, v. 101, n. 258, p. 359-381, maio/ago. 2020. Seção: Estudos.

SARMENTO, Rayza; FREITAS, Matheus. As falas sobre a fraude: análise das notícias sobre casos e fraudes nas cotas raciais em universidades em Minas Gerais. RBEP, Brasília, v. 101, n. 258, p. 271-294, maio/ago. 2020. Seção: Estudos.

SCHNEIDER, Luana Roberta; FERRAZ, Lucimare; PEREIRA, Rui Pedro Gomes; PEREIRA, Altamiro Manuel Rodrigues Costa. Ensino e aprendizagem da prática baseada em evidências nos cursos de Enfermagem e Medicina. RBEP, Brasília, v. 101, n. 257, p. 237-249, jan./abr. 2020. Seção: Relatos de Experiência.

SHIGUNOV NETO, Alexandre; CACHAPUZ, António Francisco; SILVA, André Coelho da. Formação inicial de professores de Física no Brasil e em Portugal: uma análise comparativa de modelos de formação. RBEP, Brasília, v. 101, n. 257, p. 146-163, jan./abr. 2020. Seção: Estudos.

SILVA, André Coelho da; CACHAPUZ, António Francisco; SHIGUNOV NETO, Alexandre. Formação inicial de professores de Física no Brasil e em Portugal: uma análise comparativa de modelos de formação. RBEP, Brasília, v. 101, n. 257, p. 146-163, jan./abr. 2020. Seção: Estudos.

SILVA, Bruna Emilyn da; ROSSO, Ademir José; OLIVEIRA, Vânia Katzenwadel de; SANTOS, Franciely Ribeiro dos. Representações sociais de trabalhadores com baixa escolaridade sobre o trabalho docente. RBEP, Brasília, v. 101, n. 258, p. 359-381, maio/ago. 2020. Seção: Estudos.

SILVA, Elizabeth Maria da; SILVA, Maria Ariane Santos Amaro da; CUNHA, Raquel Laurentino; BRITO, Júlia Juliêta Silva de. O que é um "bom" artigo científico? Concepções de estudantes do curso de Engenharia Elétrica. RBEP, Brasília, v. 101, n. 259, p. 771-786, set./dez. 2020. Seção: Estudos.

SILVA, Fernanda Aparecida Oliveira Rodrigues; CARVALHO, Rosana Areal; EVANGELISTA, Raquel Jesus. A disciplina Educação Moral e Cívica no Grupo Escolar Dom Benevides em Mariana/MG (1969-1975). RBEP, Brasília, v. 101, n. 258, p. 458-479, maio/ago. 2020. Seção: Estudos.

SILVA, Kleyfton Soares da; FONSECA, Laerte Silva da. Bases neuroeducativas do papel das ilustrações: uma proposta de análise de livro didático. RBEP, Brasília, v. 101, n. 257, p. 36-56, jan./abr. 2020. Seção: Estudos.

SILVA, Márcia Gorette Lima da; MAZZÉ, Fernanda. O que avalia a prova do Enade de Química? Uma proposta de análise em termos de operações cognitivas. RBEP, Brasília, v. 101, n. 259, p.721-751, set./dez. 2020. Seção: Estudos.

SILVA, Maria Ariane Santos Amaro da; SILVA, Elizabeth Maria da; CUNHA, Raquel Laurentino; BRITO, Júlia Juliêta Silva de. O que é um "bom" artigo 
científico? Concepções de estudantes do curso de engenharia elétrica. RBEP, Brasília, v. 101, n. 259, p. 771-786, set./dez. 2020. Seção: Estudos.

SOUZA, Joelson Carvalho; HICKMANN, Adolfo Antonio; ASINELLI-LUZ, Araci; HICKMANN, Girlane Moura. A influência das emoções no aprendizado dos escolares. RBEP, Brasília, v. 101, n. 258, p. 382-403, maio/ago. 2020. Seção: Estudos.

SOUZA, Juliano de TEIXEIRA, Fabiane Castilho; BROCH, Caroline; BARBOSA-RINALDI, Ieda Parra. Entre pesquisa e docência: notas sobre o projeto formativo stricto sensu em Educação Física. RBEP, Brasília, v. 101, n. 257, p. 164-181, jan./abr. 2020. Seção: Estudos.

SUASSUNA, Lívia. O ensino de análise linguística por estagiários da licenciatura em Letras. RBEP, Brasília, v. 101, n. 257, p. 57-78, jan./abr. 2020. Seção: Estudos.

TAKAYANAGUI, Axel Didriksson; CAREGNATO, Célia Elizabete; SANTIN, Dirce Maria; DEL VALLE, Dámian. Educación superior y universidad en América Latina: perspectivas temáticas para debates e investigaciones. RBEP, Brasília, v. 101, n. 259, p. 670-690, set./dez. 2020. Seção: Estudos.

TEIXEIRA, Denilson de Castro; BARROS, João Luiz da Costa; CAMPOS, Márcia Zendron de; CABRAL, Breno Guilherme de Araujo Tinoco. Reflexões sobre o nível de conhecimentos específicos dos estudantes de licenciatura em Educação Física no Enade 2014. RBEP, Brasília, v. 101, n. 257, p. 99-119, jan./abr. 2020. Seção: Estudos.

TEIXEIRA, Fabiane Castilho; SOUZA, Juliano de; BROCH, Caroline; BARBOSA-RINALDI, Ieda Parra. Entre pesquisa e docência: notas sobre o projeto formativo stricto sensu em Educação Física. RBEP, Brasília, v. 101, n. 257, p. 164-181, jan./abr. 2020. Seção: Estudos.

VALOYES, Angie Yirlesa Valoyes; DIÓGENES, Camila Gomes; EUZEBIO, Umberto. Implementación de la competencia 10 de la Base Nacional Común Curricular en Brasil: un análisis desde el concepto de Ciudadanía Global de la Agenda 2030. RBEP, Brasília, v. 101, n. 259, p. 583-606, set./dez. 2020. Seção: Estudos.

VASCONCELOS, Rafaella Lira Silva dos Santos de; WIGGERS, Ingrid Dittrich. A arte nas escolas-parque de Brasília: concepções do trabalho pedagógico. RBEP, Brasília, v. 101, n. 259, p. 547-566, set./dez. 2020. Seção: Estudos.

VIEIRA, Alexandro Braga; JESUS, Denise Meyrelles de; LIMA, Jovenildo da Cruz; MARIANO, Clayde Aparecida Belo da Silva. As contribuições de Meirieu para a formação continuada de professores e a adoção de práticas pedagógicas inclusivas. RBEP, Brasília, v. 101, n. 258, p. 503-522, maio/ago. 2020. Seção: Relatos de Experiência. 
WIGGERS, Ingrid Dittrich; VASCONCELOS, Rafaella Lira Silva dos Santos de. A arte nas escolas-parque de Brasília: concepções do trabalho pedagógico. RBEP, Brasília, v. 101, n. 259, p. 547-566, set./dez. 2020. Seção: Estudos.

WOLLINGER, Paulo; FASSINA Ana Paula; ALLAIN, Olivier. Certificação de saberes docentes na educação profissional: construção de um projetopiloto. RBEP, Brasília, v. 101, n. 259, p. 787-809, set./dez. 2020. Seção: Relatos de Experiência.

YAEGASHI, Solange Franci Raimundo; DOMINICO, Eliane; LIRA, Aliandra Cristina Mesomo; SAITO, Heloisa Toshie Irie. Práticas pedagógicas na educação infantil: o currículo como instrumento de governo dos pequenos. RBEP, Brasília, v. 101, n. 257, p. 217-236, jan./abr. 2020. Seção: Estudos. 


\section{Índice de títulos RBEP}

A serviço da Medicina: origem da disciplina de Química no Compêndio Histórico da Universidade de Coimbra (1771).

SANTOS, Ademir Valdir dos; CUSTÓDIO, Renato da Silva. A serviço da Medicina: origem da disciplina de Química no Compêndio Histórico da Universidade de Coimbra (1771). RBEP, Brasília, v. 101, n. 257, p. 182-196, jan./abr. 2020. Seção: Estudos.

Alfabetização nos Parâmetros Curriculares Nacionais (PCN) e na Base Nacional Comum Curricular (BNCC): o que mudou de 1997 a 2017, A. GUILLEN, Cássia Helena; MIGUEL, Maria Elisabeth Blanck. A alfabetização nos Parâmetros Curriculares Nacionais (PCN) e na Base Nacional Comum Curricular (BNCC): o que mudou de 1997 a 2017. RBEP, Brasília, v. 101, n. 259, p. 567-582, set./dez. 2020. Seção: Estudos.

Alteridade e interculturalidade na escola: um estudo etnográfico sobre estudantes bolivianos em São Paulo.

GONDIN, Janaina Silva; PINEZI, Ana Keila Mosca; MENEZES, Marilda Aparecida de. Alteridade e interculturalidade na escola: um estudo etnográfico sobre estudantes bolivianos em São Paulo. RBEP, Brasília, v. 101, n. 259, p. 607-626, set./dez. 2020. Seção: Estudos.

Arte nas escolas-parque de Brasília: concepções do trabalho pedagógico, A.

VASCONCELOS, Rafaella Lira Silva dos Santos de; WIGGERS, Ingrid Dittrich. A arte nas escolas-parque de Brasília: concepções do trabalho pedagógico. RBEP, Brasília, v. 101, n. 259, p. 547-566, set./dez. 2020. Seção: Estudos. 
Autoeficácia, satisfação no trabalho, aspectos sociodemográficos e condições de trabalho de docentes-alunos do PARFOR.

FERREIRA, Enizete Andrade; RAMOS, Maely Ferreira Holanda; RAMOS, Edson Marcos Leal Soares; COUTO, Andréa Lobato. Autoeficácia, satisfação no trabalho, aspectos sociodemográficos e condições de trabalho de docentes-alunos do PARFOR. RBEP, Brasília, v. 101, n. 258, p. 337-358, maio/ago. 2020. Seção: Estudos.

Bases neuroeducativas do papel das ilustrações: uma proposta de análise de livro didático.

SILVA, Kleyfton Soares da; FONSECA, Laerte Silva da. Bases neuroeducativas do papel das ilustrações: uma proposta de análise de livro didático. RBEP, Brasília, v. 101, n. 257, p. 36-56, jan./abr. 2020. Seção: Estudos.

Certificação de saberes docentes na educação profissional: construção de um projeto-piloto.

FASSINA, Ana Paula; WOLLINGER, Paulo; ALLAIN, Olivier. Certificação de saberes docentes na educação profissional: construção de um projetopiloto. RBEP, Brasília, v. 101, n. 259, p. 787-809, set./dez. 2020. Seção: Relatos de Experiência.

Contribuições de Meirieu para a formação continuada de professores e a adoção de práticas pedagógicas inclusivas, As.

VIEIRA, Alexandro Braga; JESUS, Denise Meyrelles de; LIMA, Jovenildo da Cruz; MARIANO, Clayde Aparecida Belo da Silva. As contribuições de Meirieu para a formação continuada de professores e a adoção de práticas pedagógicas inclusivas. RBEP, Brasília, v. 101, n. 258, p. 503-522, maio/ago. 2020. Seção: Relatos de Experiência.

Cursos On-line Abertos e Massivos (Mooc) como ambientes heutagógicos, Os.

AGONACS, Nikoletta; MATOS, João Filipe. Os Cursos On-line Abertos e Massivos (Mooc) como ambientes heutagógicos. RBEP, Brasília, v. 101, n. 257, p. 17-35, jan./abr. 2020. Seção: Estudos.

Dez anos de instituição da Rede Federal de Educação Profissional, Científica e Tecnológica: o papel social dos institutos federais.

NASCIMENTO, Matheus Monteiro; CAVALCANTI, Cláudio José de Holanda; OSTERMANN, Fernanda. Dez anos de instituição da Rede Federal de Educação Profissional, Científica e Tecnológica: o papel social dos institutos federais. RBEP, Brasília, v. 101, n. 257, p. 120-145, jan./abr. 2020. Seção: Estudos.

Disciplina Educação Moral e Cívica no Grupo Escolar Dom Benevides em Mariana/MG (1969-1975), A.

CARVALHO, Rosana Areal; SILVA, Fernanda Aparecida Oliveira Rodrigues; EVANGELISTA, Raquel Jesus. A disciplina Educação Moral e Cívica no Grupo Escolar Dom Benevides em Mariana/MG (1969-1975). RBEP, Brasília, v. 101, n. 258, p. 458-479, maio/ago. 2020. Seção: Estudos. 
Duas décadas da Política Nacional de Educação Ambiental: percepções de professores no contexto de uma escola pública de Pernambuco. FARIAS FILHO; Everaldo Nunes de; FARIAS, Carmen Roselaine de Oliveira. Duas décadas da Política Nacional de Educação Ambiental: percepções de professores no contexto de uma escola pública de Pernambuco. RBEP, Brasília, v. 101, n. 258, p. 481-502, maio/ago. 2020. Seção: Relatos de Experiência.

Educación superior y universidad en América Latina: perspectivas temáticas para debates e investigaciones.

CAREGNATO, Célia Elizabete; SANTIN, Dirce Maria; DEL VALLE, Dámian; TAKAYANAGUI, Axel Didriksson. Educación superior y universidad en América Latina: perspectivas temáticas para debates e investigaciones. RBEP, Brasília, v. 101, n. 259, p. 670-690, set./dez. 2020. Seção: Estudos.

Emoções experienciadas no processo de construção de narrativas digitais no Scratch.

BROCHADO, Eliana Alice; HORNINK, Gabriel Gerber. Emoções experienciadas no processo de construção de narrativas digitais no Scratch. RBEP, Brasília, v. 101, n. 259, p. 627-648, set./dez. 2020. Seção: Estudos.

Ensino de análise linguística por estagiários da licenciatura em Letras, 0.

SUASSUNA, Lívia. O ensino de análise linguística por estagiários da licenciatura em Letras. RBEP, Brasília, v. 101, n. 257, p. 57-78, jan./abr. 2020. Seção: Estudos.

Ensino e aprendizagem da prática baseada em evidências nos cursos de Enfermagem e Medicina.

FERRAZ, Lucimare; SCHNEIDER, Luana Roberta; PEREIRA, Rui Pedro Gomes; PEREIRA, Altamiro Manuel Rodrigues Costa. Ensino e aprendizagem da prática baseada em evidências nos cursos de Enfermagem e Medicina. RBEP, Brasília, v. 101, n. 257, p. 237-249, jan./abr. 2020. Seção: Relatos de Experiência.

Entre pesquisa e docência: notas sobre o projeto formativo stricto sensu em Educação Física.

TEIXEIRA, Fabiane Castilho; SOUZA, Juliano de; BROCH, Caroline; BARBOSA-RINALDI, Ieda Parra. Entre pesquisa e docência: notas sobre o projeto formativo stricto sensu em Educação Física. RBEP, Brasília, v. 101, n. 257, p. 164-181, jan./abr. 2020. Seção: Estudos.

Espaços experimentais das escolas públicas de arquitetura do Brasil: realidade ou utopia, Os?

LAVERDE, Albenise; OLIVEIRA, Cláudia Terezinha de Andrade. Os espaços experimentais das escolas públicas de arquitetura do Brasil: realidade ou utopia? RBEP, Brasília, v. 101, n. 258, p. 436-457, maio/ago. 2020. Seção: Estudos. 
Falas sobre a fraude: análise das notícias sobre casos e fraudes nas cotas raciais em universidades em Minas Gerais, As.

FREITAS, Matheus; SARMENTO, Rayza. As falas sobre a fraude: análise das notícias sobre casos e fraudes nas cotas raciais em universidades em Minas Gerais. RBEP, Brasília, v. 101, n. 258, p. 271-294, maio/ago. 2020. Seção: Estudos.

Formação inicial de professores de Física no Brasil e em Portugal: uma análise comparativa de modelos de formação.

CACHAPUZ, António Francisco; SHIGUNOV NETO, Alexandre; SILVA, André Coelho da. Formação inicial de professores de Física no Brasil e em Portugal: uma análise comparativa de modelos de formação. RBEP, Brasília, v. 101, n. 257, p. 146-163, jan./abr. 2020. Seção: Estudos.

Gestão das IES privadas sem fins lucrativos diante dos tensionamentos da mercantilização da educação superior e o caso das universidades comunitárias regionais: a caminho do hibridismo, A?

FIOREZE, Cristina. A gestão das IES privadas sem fins lucrativos diante dos tensionamentos da mercantilização da educação superior e o caso das universidades comunitárias regionais: a caminho do hibridismo? RBEP, Brasília, v. 101, n. 257, p. 79-98, jan./abr. 2020. Seção: Estudos.

Identidade docente e formação continuada: um estudo à luz das teorias de Zygmunt Bauman e Claude Dubar.

ROSSI, Fernanda; HUNGER, Dagmar. Identidade docente e formação continuada: um estudo à luz das teorias de Zygmunt Bauman e Claude Dubar. RBEP, Brasília, v. 101, n. 258, p. 313-336, maio/ago. 2020. Seção: Estudos.

Implementación de la competencia 10 de la Base Nacional Común Curricular en Brasil: un análisis desde el concepto de Ciudadanía Global de la Agenda 2030.

DIÓGENES, Camila Gomes; VALOYES, Angie Yirlesa Valoyes; EUZEBIO, Umberto. Implementación de la competencia 10 de la Base Nacional Común Curricular en Brasil: un análisis desde el concepto de Ciudadanía Global de la Agenda 2030. RBEP, Brasília, v. 101, n. 259, p. 583-606, set./dez. 2020. Seção: Estudos.

Influência das emoções no aprendizado dos escolares, A.

SOUZA, Joelson Carvalho; HICKMANN, Adolfo Antonio; ASINELLI-LUZ, Araci; HICKMANN, Girlane Moura. A influência das emoções no aprendizado dos escolares. RBEP, Brasília, v. 101, n. 258, p. 382-403, maio/ago. 2020. Seção: Estudos.

O que avalia a prova do Enade de Química? Uma proposta de análise em termos de operações cognitivas.

SILVA, Márcia Gorette Lima da; MAZZÉ, Fernanda. O que avalia a prova do Enade de Química? Uma proposta de análise em termos de operações cognitivas. RBEP, Brasília, v. 101, n. 259, p. 721-751, set./dez. 2020. Seção: Estudos. 
O que é um "bom" artigo científico? Concepções de estudantes do curso de Engenharia Elétrica.

SILVA, Elizabeth Maria da; SILVA, Maria Ariane Santos Amaro da; CUNHA, Raquel Laurentino; BRITO, Júlia Juliêta Silva de. O que é um "bom" artigo científico? Concepções de estudantes do curso de Engenharia Elétrica. RBEP, Brasília, v. 101, n. 259, p. 771-786, set./dez. 2020. Seção: Estudos.

Perfil motivacional, formas de estudo e satisfação com a vida de estudantes universitários.

HONÓRIO, Daniel Augusto; JESUS, Josiane Aparecida de; FIN, Gracielle; NODARI JÚNIOR, Rudy José. Perfil motivacional, formas de estudo e satisfação de estudantes universitários com a vida. RBEP, Brasília, v. 101, n. 258, p. 420-435, maio/ago. 2020. Seção: Estudos.

Políticas educacionais e os impactos sobre processos educativos nos cursos de pedagogia: uma análise.

FERREIRA, Liliana Soares; MACHADO, Célia Tanajura; MARASCHIN, Mariglei Severo; DE TONI, Dulcineia Libraga Papalia. Políticas educacionais e os impactos sobre processos educativos nos cursos de pedagogia: uma análise. RBEP, Brasília, v. 101, n. 258, p. 295-312, maio/ago. 2020. Seção: Estudos.

Práticas pedagógicas na educação infantil: o currículo como instrumento de governo dos pequenos.

DOMINICO, Eliane; LIRA, Aliandra Cristina Mesomo; SAITO, Heloisa Toshie Irie; YAEGASHI, Solange Franci Raimundo. Práticas pedagógicas na educação infantil: o currículo como instrumento de governo dos pequenos. RBEP, Brasília, v. 101, n. 257, p. 217-236, jan./abr. 2020. Seção: Estudos.

Praxema no contexto esportivo: a linguagem expressa pelo corpo, a exemplo do Voleibol, 0.

OLIVEIRA, Raquel Valente de; RIBAS, João Francisco Magno. O Praxema no contexto esportivo: a linguagem expressa pelo corpo, a exemplo do Voleibol. RBEP, Brasília, v. 101, n. 258, p. 404-419, maio/ago. 2020. Seção: Estudos.

Reflexões sobre o nível de conhecimentos específicos dos estudantes de licenciatura em Educação Física no Enade 2014.

BARROS, João Luiz da Costa; CAMPOS, Márcia Zendron de; TEIXEIRA, Denilson de Castro; CABRAL, Breno Guilherme de Araujo Tinoco. Reflexões sobre o nível de conhecimentos específicos dos estudantes de licenciatura em Educação Física no Enade 2014. RBEP, Brasília, v. 101, n. 257, p. 99-119, jan./abr. 2020. Seção: Estudos.

Representações sociais de trabalhadores com baixa escolaridade sobre o trabalho docente.

ROSSO, Ademir José; SILVA, Bruna Emilyn da; OLIVEIRA, Vânia Katzenwadel de; SANTOS, Franciely Ribeiro dos. Representações sociais de trabalhadores com baixa escolaridade sobre o trabalho docente. RBEP, Brasília, v. 101, n. 258, p. 359-381, maio/ago. 2020. Seção: Estudos. 
Sobre uma práxis interdisciplinar: aproximações e proposições conceituais.

RAMOS, Luiza Olivia Lacerda; FERREIRA, Rosilda Arruda. Sobre uma práxis interdisciplinar: aproximações e proposições conceituais. RBEP, Brasília, v. 101, n. 257, p. 197-216, jan./abr. 2020. Seção: Estudos.

Trabalho pedagógico nos cursos de licenciatura da Universidade Estadual de Londrina: metodologias em questão.

ROCATELI, Adrielly; FRANCO, Sandra Aparecida Pires; GALVÃO, Rosangela Miola; CASAGRANDE, Fernanda Couto Guimarães. Trabalho pedagógico nos cursos de licenciatura da Universidade Estadual de Londrina: metodologias em questão. RBEP, Brasília, v. 101, n. 259, p. 752-770, set./dez. 2020. Seção: Estudos.

Três componentes executivos básicos e o desempenho matemático escolar, Os.

SANTANA, Alanny Nunes de; ROAZZI, Antonio; MELO, Monilly Ramos Araújo. Os três componentes executivos básicos e o desempenho matemático escolar. RBEP, Brasília, v. 101, n. 259, p. 649-669, set./dez. 2020. Seção: Estudos.

Value-added measures in higher education: a historical contextualization of Brazilian experiences.

FERNANDES, Vivian Duarte Couto; MIRANDA, Gilberto José; ALEXANDER, Nicola. Value-added measures in higher education: a historical contextualization of Brazilian experiences. RBEP, Brasília, v. 101, n. 259, p. 691-720, set./dez. 2020. Seção: Estudos. 



\section{DIRETRIZES PARA AUTORES RBEP}

Vigência 2020

A Revista Brasileira de Estudos Pedagógicos (RBEP) publica apenas textos inéditos. É um periódico de acesso aberto sob licença Creative Commons, portanto, permite compartilhar, distribuir, exibir e fazer trabalhos derivados de seu conteúdo, desde que se atribuam os créditos devidos.

A exatidão das informações e os conceitos e opiniões emitidos nos textos submetidos são de exclusiva responsabilidade dos autores (as), não refletindo, necessariamente, a opinião da equipe editorial da Revista.

A RBEP prima pelas boas práticas científicas com base nas diretrizes do Comittee on Publication Ethics (Cope) e empenha-se em coibir más condutas, como plágio ou possíveis violações éticas.

\section{Submissão}

Os textos são encaminhados exclusivamente por meio do Open Jornal System - OJS (rbep.inep.gov.br/ojs3)^ cujo acesso é realizado mediante cadastro anterior.

\section{Tipos de textos aceitos na RBEP}

2.1 Estudos - artigos resultantes de pesquisas empíricas e teóricas com objetivos claros, fundamentação teórica e adequação metodológica que respaldem a discussão apresentada, considerando que: 
a) pesquisas empíricas devem explicitar procedimentos de pesquisa, critérios para constituição da amostra ou seleção dos sujeitos, métodos de coleta, construção e análise dos dados e aprovação do conselho de ética, quando for o caso.

b) pesquisas teóricas devem evidenciar elaboração original sobre tema e questão de relevância para a área de educação.

2.2 Relatos de Experiência - artigos que relatem projetos inovadores de intervenção pedagógica na área de educação, com análise crítica e reflexiva de processos e resultados, contextualizados e metodologicamente fundamentados.

2.3 Resenhas - análise crítica de livros ou filmes lançados nos últimos três anos relacionados à educação. As resenhas devem apresentar título, referência da obra, dados dos autores/ diretores da obra resenhada, resumo e posicionamento analítico do resenhista sobre as contribuições da obra para a área.

\section{Normas gerais para apresentação dos originais}

3.1 Idiomas: os textos podem ser redigidos em português, espanhol ou inglês.

3.1.1 Os textos em espanhol ou inglês devem ser submetidos devidamente revisados por especialista na língua. A comprovação deverá ser realizada por meio de declaração assinada pelo revisor e submetida como documento suplementar.

\subsection{Autoria:}

3.2.1 O número de autores por artigo científico e relato de experiência não poderá exceder o total de quatro pessoas.

3.2.2 O número de autores por resenha não poderá exceder o total de duas pessoas.

3.2.3 Na RBEP, consideram-se autores aqueles que tenham contribuído de forma substancial em todas as seguintes etapas do trabalho:

(1) concepção e delineamento do estudo, aquisição de dados ou análise e interpretação de dados;

(2) redação do artigo ou revisão crítica do conteúdo; e

(3) aprovação final da versão submetida.

3.2.4 Para os demais colaboradores (estagiários, auxiliares de pesquisa etc.), deve-se anexar como documento 
suplementar, no ato de submissão, uma declaração em que sejam especificadas as contribuições individuais de cada um. Essa informação será publicada, ao final do artigo, em um subtítulo separado denominado "Colaborações".

3.2.5 A identificação de autoria do texto deve ser removida, assim como devem ser retirados do texto todos os nomes de autores, grupos de pesquisa e instituições. Recomenda-se o uso de "XXX» em substituição a quaisquer referências, incluindo as bibliográficas, que possam identificar a autoria.

3.2.6 É preciso remover a autoria do arquivo por meio da opção Propriedades, no Microsoft Word, garantindo, dessa forma, o critério de anonimato dos textos submetidos.

3.2.7 Todos os autores devem ser cadastrados no ato da submissão no sistema da Revista. Em nenhuma hipótese serão acrescentados ou retirados nomes após o início da avaliação.

3.2.8 Os autores que tiverem texto aprovado para publicação deverão respeitar o prazo de 24 meses para realizar uma nova submissão. Artigos de autores recém-publicados que venham a ser submetidos à revista serão arquivados.

3.2.9 A aceitação do texto pela revista implica automaticamente a cessão de seus direitos autorais ao Instituto Nacional de Estudos e Pesquisas Educacionais Anísio Teixeira (Inep).

3.2.10 A RBEP reserva-se o direito de efetuar alterações nos originais, respeitados o estilo e as opiniões dos autores, com vistas a manter a qualidade do periódico.

3.3 Mídia: os textos podem ser submetidos no formato Microsoft Word (.doc e .docx), Open Office (.odt) ou RTF, configurados com entrelinhas 1,5, e conter entre 28.000 e 55.000 caracteres, incluindo os espaços (a extensão do artigo inclui título, resumo, palavras-chave nos três idiomas e referências).

3.3.1 Os arquivos não devem exceder o tamanho de 2MB.

3.3.2 O texto deve ser formatado conforme template (acessar o site: www.rbep.gov.br).

3.3.3 O nome do arquivo enviado não pode ultrapassar a extensão de 85 caracteres.

3.4 Fonte: Times New Roman, em corpo 12 para o texto, corpo 10 para as citações destacadas e corpo 8 para as notas de rodapé.

3.5 Ilustrações: as imagens devem possuir resolução a partir de 300 dpi e estar acompanhadas das fontes e de título que permita compreender o significado dos dados reunidos. Os quadros, 
tabelas e gráficos (de preferência em Excel) devem vir em preto e branco e obedecer às normas de apresentação tabular do Instituto Brasileiro de Geografia e Estatística (IBGE).

3.6 Título: o título do artigo deve ser breve (máximo de 200 caracteres com espaço), específico e descritivo, contendo palavras representativas do seu conteúdo, e vir, também, traduzido para o inglês e espanhol.

3.7 Resumos: os artigos devem ter, obrigatoriamente, resumos informativos em português, inglês e espanhol, com até 1.500 caracteres com espaço.

3.7.1 Os resumos devem conter informações qualitativas e quantitativas e dados essenciais, como:

a) Descrição - indica o tipo de artigo a ser analisado (artigo original, de revisão, estudo de caso) e a natureza do problema tratado.

b) Objetivo - ressalta o que se pretende e o que se buscou demonstrar com o trabalho.

c) Justificativa - descreve as razões pelas quais o trabalho foi realizado.

d) Metodologia - descreve a abordagem, o referencial teórico e metodológico empregado, bem como as principais técnicas utilizadas. Indica as fontes dos dados e o modo como estes foram usados, quais os conceitos desenvolvidos e como foram analisadas as variáveis.

e) Resultados - descrevem sucintamente as descobertas significativas e importantes da pesquisa.

3.8 Palavras-chave: os artigos devem apresentar entre três e cinco palavras-chave referentes ao seu conteúdo, escolhidas, quando possível, em vocabulário controlado - Thesaurus Brasileiro de Educação, - e vir traduzidas para o inglês e o espanhol.

3.9 Citações: as citações devem seguir as normas da Associação Brasileira de Normas Técnicas (ABNT NBR 10.520/2002).

3.9.1 As citações diretas com até três linhas devem vir entre aspas, dentro do parágrafo, acompanhadas por uma chamada entre parênteses para o autor, o ano e o número da página da publicação.

3.9.2 As citações diretas com mais de três linhas devem ser destacadas com recuo, sem aspas, em corpo 10, redondo.

3.9.3 A referência bibliográfica completa da citação virá em lista única ao final do artigo. 
3.9.4 - A exatidão e a adequação das citações e referências a trabalhos consultados e mencionados no texto são de responsabilidade do autor do artigo submetido.

3.9.5 A omissão de referência de citações diretas ou indiretas pode caracterizar plágio (ver item 7.2).

3.10 Notas: as notas de rodapé devem ser evitadas. Se necessárias, devem ter a finalidade de oferecer observações complementares; realizar remissões internas e externas; introduzir uma citação de reforço; ou fornecer a tradução de um texto. As indicações das fontes bibliográficas devem ser feitas no texto.

3.11 Referências bibliográficas: as referências bibliográficas devem constituir uma lista única no final do artigo, em ordem alfabética por sobrenome de autor; devem ser completas e elaboradas de acordo com as normas da Associação Brasileira de Normas Técnicas (ABNT NBR 6023/2002).

3.11.1 Quando se tratar de obra consultada on-line, é necessário indicar o endereço eletrônico e a data em que foi acessado; se a obra estiver em suporte eletrônico (DVD, CDROM), essa informação também deve constar após a sua identificação.

3.11.2 Todos os endereços de páginas na internet (URLs) incluídas no texto (Ex.: http://www.ibict.br) devem estar ativos.

3.12 Siglas: as siglas devem vir precedidas do nome por extenso.

3.13 Destaques: o uso de negrito deve ficar restrito aos títulos e intertítulos; o de itálico, apenas para destacar conceitos ou grifar palavras em língua estrangeira.

3.14 As resenhas devem seguir as mesmas exigências indicadas para os demais gêneros textuais, no entanto, devem possuir extensão entre 10.000 e 15.000 caracteres, considerando os espaços.

3.15 A não observância das normas gerais de apresentação dos textos ensejará o arquivamento da submissão. Assim como a inadequação da submissão ao foco e ao escopo da Revista.

\section{Processo de avaliação}

\subsection{Avaliação cega por pares (1 ${ }^{a}$ etapa)}

4.1.1 Os artigos são avaliados por dois consultores ad hoc de reconhecida competência nos temas abordados, 
diversificados regional e institucionalmente. Os artigos são encaminhados sem identificação de autoria tanto para os avaliadores ad hoc como para a Editoria Científica para garantir imparcialidade na avaliação.

4.1.2 A Editoria Científica é composta por conceituados especialistas, proeminentes em diferentes linhas de pesquisa da área de educação de diferentes instituições do país.

4.1.3 Serão considerados na primeira etapa de avaliação de mérito dos textos os seguintes critérios:
a) relevância do tema para a área de estudo;
b) clareza na exposição do objeto de estudo, objetivos e justificativa;
c) pertinência e atualidade da bibliografia;
d) consistência teórico-metodológica;
e) rigor na utilização dos conceitos;
f) adequação argumentativa da análise dos resultados.

4.1.4 Os pareceres envolvem três tipos de julgamento:

a) Aprovado - o artigo está aceito para publicação.

b) Correções obrigatórias - são solicitados ao autor ajustes ou reformulações no artigo, com o envio de nova versão para avaliação final.

c) Não aprovado - o artigo é rejeitado.

4.1.5 No caso de o texto receber duas avaliações indicando a não publicação, a submissão será arquivada nesta etapa do processo e o autor será comunicado.

\subsection{Decisão da Editoria Científica (2 ${ }^{a}$ etapa)}

A aprovação final dos textos é de responsabilidade da Editoria Científica da RBEP, mediante a emissão de parecer consolidado. A Editoria Científica decidirá pela pertinência da publicação dos textos submetidos, conforme os objetivos de cada seção e o escopo da Revista.

4.2.1 O atendimento das condições especificadas nas "Normas gerais para a apresentação de originais" (item 3) é imprescindível para a publicação do artigo.

4.2.2 Nesta etapa, os autores receberão comunicado, por meio de sistema eletrônico, informando sobre a decisão da editoria científica (aceito, rejeitado ou alterações obrigatórias). 
Caso a decisão indique correções obrigatórias, o texto reformulado será submetido à terceira e última rodada de avaliação. A Editoria Científica reserva-se o direito de recusar artigos cujas modificações não atendam às suas recomendações.

4.3 Os avaliadores e editores devem manter sigilo sobre os artigos avaliados e não podem utilizar informações, dados, argumentos ou análises sem autorização prévia dos autores.

4.4 Caso os avaliadores suspeitem de má conduta científica, devem comunicá-la à Editoria Executiva da Revista.

\section{Agradecimentos}

5.1 Organizações privadas ou governamentais que forneceram apoio ou financiamento para a pesquisa devem ser mencionadas de forma objetiva.

5.2 Os autores são responsáveis pelas menções a pessoas e instituições.

5.3 Essas informações devem ser registradas em documento suplementar no ato da submissão.

\section{Diretrizes éticas}

6.1 Originalidade: a submissão de um original implica que o trabalho:

a) não foi publicado anteriormente (exceto sob a forma de resumo ou como parte de uma palestra ou tese/dissertação acadêmica, devidamente referenciados no artigo);

b) não está sendo avaliado para publicação em outra revista;

c) se aceito, não será publicado em outro periódico, em qualquer outro idioma, inclusive eletronicamente, sem o consentimento por escrito do detentor dos direitos autorais.

6.2 Não se admite o uso não referenciado de ideias, conceitos, análises, imagens e textos (ou fragmentos de textos) de outros.

6.3 Detecção de plágio: para verificar a originalidade, o trabalho será submetido ao software de detecção de plágio Similarity Check.

6.4 Publicação redundante (autoplágio): não se deve republicar o mesmo trabalho sob novo título ou se apropriar de parte significativa de texto já publicado pelo mesmo autor.

6.5 Trechos de textos já publicados do mesmo autor em outras revistas com ISSN ou livros com ISBN devem ser devidamente 
referenciados e não podem exceder o limite de 30\% do total do artigo original submetido à RBEP.

6.6 Uma vez identificado plágio, superior a 30\%, o autor ficará impedido de submeter novo artigo à Revista por um período de 24 meses.

6.7 Observar as normas aplicáveis a pesquisas em Ciências Humanas e Sociais, quando os procedimentos metodológicos envolverem a utilização de dados diretamente obtidos com participantes ou informações identificáveis, na forma definida pela Resolução CNS, $n^{\circ}$ 510, de 07 abril de 2016.

6.8 Análise de má conduta científica: todas as suspeitas de má conduta científica serão analisadas primeiramente pela Editoria Executiva que encaminhará relatório técnico para deliberação da Editoria Científica.

6.9 Política de retratação: caso se conclua que houve, intencionalmente ou por desconhecimento, má conduta por parte dos autores, a RBEP poderá adotar as seguintes medidas:

a) advertir o autor;

b) arquivar o artigo ainda no processo de avaliação ou edição;

c) retirar o artigo da revista on-line, no caso de já publicado;

d) dar publicidade na Revista ao fato ocorrido, caso o artigo já tenha sido publicado. 


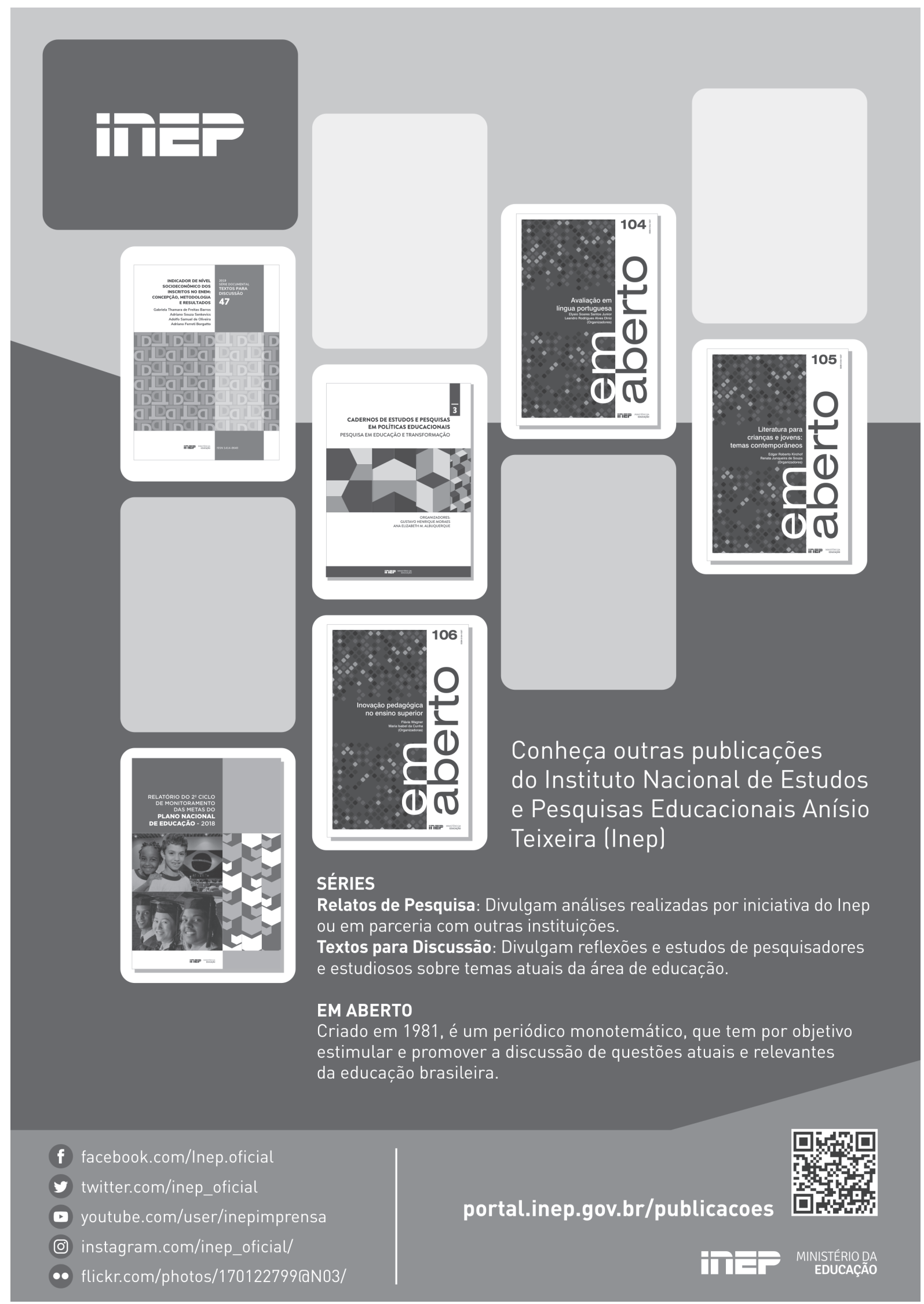


Esta obra foi impressa em Uberlândia-MG,

pela Gráfica Tavares \& Tavares em 2020.

Capa impressa em papel cartão supremo $250 \mathrm{~g}$ e miolo em papel off-set $90 \mathrm{~g}$.

Texto composto em Eggo corpo 10. 